Article

\title{
Sports, Transgender Rights and the Bodily Politics of Cisgender Supremacy
}

\author{
Elizabeth A. Sharrow ${ }^{1,2}$ (D) \\ 1 School of Public Policy, University of Massachusetts Amherst, Amherst, MA 01003, USA; \\ esharrow@umass.edu \\ 2 Department of History, University of Massachusetts Amherst, Amherst, MA 01003, USA
}

check for updates

Citation: Sharrow, Elizabeth A. 2021. Sports, Transgender Rights and the Bodily Politics of Cisgender Supremacy. Laws 10: 63. https: / / doi.org/10.3390/ laws10030063

Received: 29 May 2021 Accepted: 27 July 2021 Published: 31 July 2021

Publisher's Note: MDPI stays neutral with regard to jurisdictional claims in published maps and institutional affiliations.

Copyright: (C) 2021 by the author. Licensee MDPI, Basel, Switzerland. This article is an open access article distributed under the terms and conditions of the Creative Commons Attribution (CC BY) license (https:// creativecommons.org/licenses/by/ $4.0 /)$.

\begin{abstract}
Between 2020 and 2021, one hundred and ten bills in state legislatures across the United States suggested banning the participation of transgender athletes on sports teams for girls and women. As of July 2021, ten such bills have become state law. This paper tracks the political shift towards targeting transgender athletes. Conservative political interests now seek laws that suture biological determinist arguments to civil rights of bodies. Although narrow binary definitions of sex have long operated in the background as a means for policy implementation under Title IX, Republican lawmakers now aim to reframe sex non-discrimination policies as means of gendered exclusion. The content of proposals reveal the centrality of ideas about bodily immutability, and body politics more generally, in shaping the future of American gender politics. My analysis of bills from 2021 argues that legislative proposals advance a logic of "cisgender supremacy" inhering in political claims about normatively gendered bodies. Political institutions are another site for advancing, enshrining, and normalizing cis-supremacist gender orders, explicitly joining cause with medical authorities as arbiters of gender normativity. Characteristics of bodies and their alleged role in evidencing sex itself have fueled the tactics of anti-transgender activists on the political Right. However, the target of their aims is not mere policy change but a state-sanctioned return to a narrowly cis- and heteropatriarchal gender order.
\end{abstract}

Keywords: sports; Title IX; transgender; cisgender; state legislatures

\section{Introduction}

During the 2020 state legislative season, legislators in twenty American states introduced proposals to ban transgender (or "trans") girls from competing on girl's high school (and, in some cases, also women's college) sports teams. ${ }^{1}$ In Idaho, the governor signed a proposed bill (H.B. 500) into law on 30 March 2020 making it the first state to impose an outright ban on athletic participation for transgender girls and women in school-sponsored sports. Throughout early 2021, legislatures in thirty-six states considered such bills. ${ }^{2}$ Alabama, Arkansas, Florida, Mississippi, Montana, Tennessee, and West Virginia followed Idaho to pass their own versions of transgender sports participation bans that year; South Dakota's governor issued two Executive Orders, which in effect implemented a similar

1 Throughout, I make reference to identities and categories of sex, gender and gender identity (i.e., the gender one regards themself). Language of sex and gender are constantly evolving, so here I use: (1) "cisgender women/girls", by which I mean those who identify with the sex they were assigned at birth; (2) "transgender women/girls", which refers to an umbrella category of people who disidentify with the sex they are assigned at birth and who may identify as a woman/girl and/or who seek inclusion in competitive athletic teams designated for "girls" or "women" irrespective of whether they wholly identify as a girl/woman/female (e.g., non-binary, intersex, genderfluid, gender non-conforming people may identify as transgender and seek inclusion as athletes on teams for women; see DeLaCretaz 2021); and (3) "women/girls". Unless specified, references to "women/girls" connote all those who identify as such, whether cis or trans.

2 The composition of states considering legislation in 2021 included sixteen states where bans were also considered in 2020 , and twenty states with legislation introduced only in 2021. Four states considered legislation in 2020 but not 2021. See footnotes 22 and 37 for specifics. 
prohibition. ${ }^{3}$ This legislative activity unfolded concurrent with a Connecticut court case filed in February 2020 by the Alliance Defending Freedom that sought to ban two Black, transgender girls from competing in high school track and field. ${ }^{4}$

The legislative and legal push to ban transgender athletes from school-sponsored athletics has inordinately focused on barring transgender girls and has been almost unilaterally advanced by Republican lawmakers and conservative interest groups. The substance of this swell of activity overwhelmingly focuses on the athlete's bodies, a long-time topic of fascination for policy makers charged with advancing equity in girl's and women's sports (see Sharrow 2017). ${ }^{5}$ Historically, sex non-discrimination policies (i.e., Title IX of the Education Amendments of 1972 and Title VII of the Civil Rights Act of 1964) have provided pathways for increasing inclusion of girls and women in androcentric realms (Rose 2018; Turk 2016). ${ }^{6}$ However, during an era where definitions of gender and identity are being overtly renegotiated (Halberstam 2018), new proposals aim to restrict access for transgender people to spaces designated for women and girls. The methods proposed for enacting such restrictions are fundamentally tied to the surveillance of gendered bodies.

This paper tracks the political shift towards targeting transgender athletes in the context of the broader anti-LGBTQ+ political movement. Conservative political interests now seek laws that suture biological determinist arguments to civil rights of bodies. Although narrow binary definitions of sex have long operated in the background as a means for policy implementation under Title IX (Sharrow 2017), Republican lawmakers now aim to reframe sex non-discrimination policies as means of gendered exclusion. Such transexclusionary ideas and political agendas are not new (see Wuest 2021), but the content of current proposals reveal the centrality of the physical body itself-and body politics more generally-in shaping the future of American gender politics.

Recent legislative proposals advance what I call "cisgender supremacy", a logic that inheres in political assertions about normatively gendered bodies. Political institutions have emerged as another site for advancing, enshrining, and normalizing cis-supremacist gender orders, explicitly joining cause with medical authorities as arbiters of gender normativity (see also Fausto-Sterling 2000; Gill-Peterson 2018; Karkazis 2008; Shuster 2021). Characteristics of bodies and their alleged role in evidencing sex itself fuel the tactics of anti-transgender activists on the political Right. However, my analyses reveal that the target of their aims is not mere policy change but a state-sanctioned return to a narrowly cis- and heteropatriarchal gender order.

\section{Purpose and Outline}

I present a thematic analysis of the proposed legislative tactics for transgender exclusion (Braun and Clarke 2012, 2021). I contextualize the current debates over trans inclusion in the history of sex non-discrimination policy that has long-subsumed discussion about who "counts" as a woman or a girl, and who is eligible for girl's and women's athletic teams. I contend that policy makers and actors on the political Right (by which I mean the formal U.S. Republican Party and its ideologically-affiliated advocacy groups; see Wuest 2021 for lengthier discussion and Schreiber 2008 for the Right's long-standing affiliation with anti-feminist aims) now target the realm of sports because of its narrow reliance on sex segregation, a policy design that invites bodily surveillance under Title IX. I describe

3 In addition to sports legislation, an array of other anti-trans bills seeking to ban access to gender-affirming health care, restrict access to segregated public and school bathrooms, or deny changes to sex designated on birth certificates were proposed by lawmakers. As of June 2021, thirteen anti-transgender bills (including sports bans) were passed into state law during the 2021 session (Levin 2021; MAP 2021b).

4 Soule et al. v. CT Association of Schools et al., No. 3:20-cv-00201 (D. Conn. 2020).

5 This article focuses on school-sponsored athletics but women's elite athletics also have a long, racialized history of surveilling women's bodies through the customs of sex testing (Pieper 2016), which employ white, Western standards of femininity to exclude predominately women of color from the Global South (Karkazis and Jordan-Young 2018).

620 U.S.C. $§ 1681$ et seq; Pub. L. 88-352. 
five themes within the 2021 proposed legislation that illustrate how cisgender supremacy manifests in current politics.?

This article begins by framing current politics in the context of sports and as they relate to bodies and Title IX. Next, I describe the events of the 2020 and 2021 state legislative sessions and cast these events against the backdrop of state-level struggles for LGBTQ+ recognition and equality. I explain the federal-level policy environment and the relationship between debates over transgender inclusion and school-sponsored sports. Finally, I analyze themes within 2021 proposed state-level policies and employ concepts and frameworks from intersectional gender studies (e.g., Collins 2000; Crenshaw 1989) to illustrate how a cisgender supremacist order is constituted by political debates defining sex non-discrimination at the intersections of gender, race, sexuality and physical ability. The constructions of transgender identity are inherently racialized (Snorton 2017), particularly in this instance because the trans athletes targeted for exclusion in the Connecticut legal battle are girls of color. When pressed, state lawmakers have been unable to identify any other transgender athletes in their states whose athletic participation is controversial (Crary and Whitehurst 2021). Reading policy debate through an intersectional feminist lens demonstrates that the politics of women's rights in sport remain highly fraught with assumptions about biology and whiteness a half-century after the passage of Title IX.

\section{Sports, Bodies, and Title IX}

The history of sex non-discrimination in school-sponsored athletics is a chronicle of Title IX of the Education Amendments of 1972 (Brake 2010). ${ }^{8}$ In effect, Title IX's implementation dramatically reshaped opportunities for girls and women in American education by outlawing their exclusion from graduate and professional schools, facilitating the expansion of athletic opportunities, and broadening the legal and policy conversations about sexual harassment, pregnancy and parenting discrimination (Eckes 2021). The benefits of policy have been primarily enjoyed by white, able-bodied girls and women from middle-toupper-income families (NWLC and PRRAC 2015; Pickett et al. 2012) leading extant critique to focus on the intersectional failures of single-dimension non-discrimination policy (see also Crenshaw 1989). Nearly fifty years after its passage, Title IX remains the primary federal-level protection against sex discrimination in American education.

Title IX is modeled on the Civil Rights Act of 1964 (CRA), yet when lawmakers and feminist activists considered amending the CRA to address sex discrimination in education, they engaged in notably little public-facing discussion. In 1970, only two congressional hearings were convened on the evolving evidence of sex bias in educational access, curricular materials, faculty hiring, and related topics (Fishel and Pottker 1977). With Congress concerned about the ongoing process of racially desegregating schools, supporters of nascent federal-level protections banning discrimination against women elected to downplay lobbying efforts supporting Title IX and to limit congressional discussion (Rose 2018). When a sex non-discrimination provision passed as the ninth title (i.e., "Title IX") in the bill it was implied, but not openly discussed, that such protections had cisgender girls and women in mind.

Lawmakers scarcely considered sports in the congressional record before Title IX's passage (Sharrow 2017). It was only during subsequent bureaucratic discussion of implementation guidelines that the question of how to realize athletic equity came to the fore. Before the 1970s, school-sponsored athletic opportunities dramatically favored boys and men, leaving girls and women to confront exclusion (Cahn 1995). In 1971, girls comprised only seven percent of high school athletes (NFHS 2019) and women's exclusion was even

7 I select this focus on state legislatures for research design and analysis purposes to focus on the record of lawmaking. I situate lawmaking in its discursive political context which is shaped by "trans-exclusionary radical feminists" (TERFs) (Goldberg 2014). TERF circles emerged from second-wave liberal feminist movements and have more recently joined cause with conservative interest groups to contest trans inclusion under sex non-discrimination policies (Pearce et al. 2020; Wang 2019; Wuest 2021).

8 Title IX states that "no person ... shall, on the basis of sex, be excluded from participation in, be denied the benefits of, or be subjected to discrimination under any education program or activity receiving Federal financial assistance" [20 U.S.C. § 1681(a)]. 
more pronounced at the collegiate level. In 1971, before Title IX became law, women experienced only fifteen percent of collegiate athletic opportunities (NCAA 2014).

Today, almost every high school and collegiate athlete participates on sex-segregated teams. The reason for this practice is structural. Title IX's policy design has, since the 1970s, required schools to provide teams specifically for women and girls (DOE 1979); only under limited circumstances may girls compete on boy's teams or vice versa (Love and Kelly 2011). However, policy makers and activists seriously debated this policy model in the 1970s before deciding to implement it (see full history in Sharrow 2017). Feminist activists were concerned about the impacts of historic marginalization, including the lack of training, coaching, facilities, and support for girls and women with athletic aspirations. The lack of investment by most schools and colleges left the preponderance of girls and women under-prepared to swiftly assimilate into a sports world designed for boys and men. Still, some second-wave feminist groups like the National Organization for Women (NOW) maintained that moving toward sex-integrated sports over time would best challenge the sexist presumptions that propelled discrimination, including the generic assumption that all girls and women would fail in competition with all boys and men (Sharrow 2017). Yet, sex-segregated structures presumed that categorizing athletes for competition is apolitical. Although transgender children certainly existed then (Gill-Peterson 2018), as now (Meadow 2018), the explicit tensions embedded in policy design for interscholastic and intercollegiate athletics would not surface for some years. ${ }^{9}$

A sizable cadre of scholars and activists echo the concerns voiced by NOW that strictly sex-segregated teams can quietly undermine full equality for women and girls. Segregation blocks girls and women from accessing the highest-profile and best-funded athletic opportunities which continue to be reserved for boys and men (Buzuvis 2019; Leong 2018; McDonagh and Pappano 2007; Milner and Braddock 2016; Sharrow 2021). Adherence to Title IX's segregated policy design suppresses evidence of the abilities (and desires) of many girls and women to compete with boys and men, and vice versa (Klecker 2019; McKinney 2019). Less than half (44\%) of school-sponsored athletic participation opportunities fall to girls and women (NCAA 2021), and the vast majority of U.S. high school and collegiate sports teams remain sex segregated to this day (NCAA 2017; NFHS 2019).

In addition to establishing a fraught context for the full inclusion of transgender athletes, segregation enables unequal support for and value of women's sports. Sports for girls and women remain severely under-funded (Staurowsky et al. 2020), opportunities for women in coaching and athletic leadership have substantially decreased in the past decades (Sabo et al. 2016; Whisenant 2003), female athletes remain vulnerable to sexual harassment and abuse (Macur and Levenson 2021; Novkov 2019), media coverage of women's sports falls well below that of men's (Cooky et al. 2021), and when women athletes are covered it is more likely to be through sexualizing frames (Musto et al. 2017; Musto and McGann 2016).

Segregatory practices also establish sports as a remarkable outlier. In other realms, laws and policies have eradicated most de jure male-exclusive institutions (see, i.e., Strum 2002). Very few jurisdictions remain differentiated explicitly by sex, excepting public restrooms and locker rooms. ${ }^{10}$ Historically sex-exclusive institutions-including U.S. military academies, firefighting and policing squads, and military combat forcesare now legally required to integrate women into their ranks, though integration has benefited cisgender more than transgender women. At the same time, enduring single-sex institutions, like women's colleges, have frequently drawn the unique ire of anti-trans forces where gender transgressive people are frequently targeted (Davis 2018; Nanney and Brunsma 2017). From excluding transgender women from cultural events like the

9 Renée Richards' battle to participate as an out, transgender woman throughout the 1970s in the women's professional tennis circuit highlighted questions about trans inclusion in women's sport, but the conversations in that era were largely contained to the professional level and operated to preserve binary competitive categories (see Pieper 2012).

10 On the histories of conflicts over incorporating transgender students in these realms, see Davis (2020) and Cunningham et al. (2018). 
Michigan Womyn's Music Festival, to court battles over access to bathrooms and locker rooms at school, surveillance of transgender people is often most acute where sex-based identities are the most salient (Beauchamp 2019; Davis 2020; Stratford 2020). In these policy and social contexts, sports are ripe for conflict.

\section{Existing Policies in States and Schools}

In light of this history, efforts to negotiate the inclusion of transgender athletes in segregated sports are ongoing. In recent years, many high school sports governing bodies have created inclusion policies for transgender and non-binary athletes. In 2011, the National Collegiate Athletic Association (NCAA) announced guidelines for participation of transgender athletes in NCAA-sponsored collegiate athletics, though these guidelines allow for significant latitude in implementation at each institution and are only enforceable during NCAA championships (Griffin and Carroll 2011). At the high school level there has been important innovation for inclusion over the past decade, but there remains significant variation across the states where competitive eligibility is determined by state high school athletic associations (GLSEN 2021; see links to state policies in Mosier 2021). Guidance in some states enables eligibility based on an athlete's gender identity. ${ }^{11}$ Other states make inclusion of transgender athletes conditional on medical interventions (e.g., gender-affirming surgery, which remains extremely unlikely for children under 18). ${ }^{12}$ Still others only allow participation in the category indicated on an athlete's birth certificate. ${ }^{13}$ Numerous state association policies place various discriminatory restrictions on participation for transgender athletes, such as leaving ad hoc determinations about eligibility to the student's school administrators, or by requiring invasive oversight by medical doctors. ${ }^{14}$ Ten states have no articulated policies for governing participation of transgender athletes in interscholastic sports. ${ }^{15}$

Notably, state non-discrimination laws also vary in their enumerated protections against gender identity discrimination in schools, and federal-level LGBTQ+ protections remain limited (MAP 2021a). ${ }^{16}$ Thus, the policy and legal landscape across the states constitute what scholars refer to as "fragmented federalism" where the rights of transgender athletes (and LGBTQ+ students more generally) are contingent on the state where they live or the school where they are enrolled (Taylor et al. 2021). By consequence, the inclusion of trans and gender non-conforming athletes remains contingent and uneven (Buzuvis 2021) even notwithstanding the 2020 and 2021 legislative activity aimed to enshrine their exclusion into law.

\section{National Context and State-Level Politics in the 2020 and 2021 Legislative Sessions}

Recent policy disputes hinge on whether existing sex non-discrimination policies designed to support the needs of cisgender women will apply to the fortunes of transgender, non-binary, intersex, and gender non-conforming/genderfluid people. They are rooted in a half-century of national-level, anti-gay organizing within the Christian Right (Herman 1997; Self 2012) that has polarized stances on LGBTQ+ rights among partisan elites (Bishin et al. 2020). Next, I delineate the form and sequence of recent political events to contextualize the current conflict.

11 During the 2020-2021 school year, those states included California, Colorado, Connecticut, Florida, Maryland, Massachusetts, Minnesota, Nevada, New Hampshire, New Jersey, New York, Oregon, Rhode Island, Vermont, Washington, and Washington D.C. (GLSEN 2021).

12 During the 2020-2021 school year, these states included Indiana, Kentucky, and Louisiana (GLSEN 2021).

13 During the 2020-2021 school year, those states included Alabama, Arkansas, Georgia, Idaho, New Mexico, and Texas (GLSEN 2021).

14 During the 2020-2021 school year, those states included Arizona, Delaware, Illinois, Iowa, Maine, Missouri, Nebraska, North Dakota, North Carolina, Oklahoma, Ohio, South Dakota, Utah, Virginia, Wisconsin, and Wyoming (GLSEN 2021).

15 During the 2020-2021 school year, these states included Alaska, Hawaii, Kansas, Michigan, Mississippi, Montana, Pennsylvania, South Carolina, Tennessee, and West Virginia (GLSEN 2021).

16 Seventeen states (plus D.C.) currently have laws that prohibit discrimination in schools on the basis of gender identity and sexual orientation. Six others have policy that interprets other existing laws as enacting such protections. But twenty-seven states have no laws protecting LGBTQ+ students from discrimination, and two states (Missouri and South Dakota) have laws that prevent schools from penning their own non-discrimination policies (see MAP 2021a). 


\subsection{National Context from 2017 through 2020}

Political attacks on the legitimacy of transgender identity are long-standing (Murib 2020; Schilt and Westbrook 2015; Taylor 2007), though pointedly accelerated by federal leadership under Donald Trump's presidential administration. From the hastily announced ban on transgender military participation (see summary in Taylor et al. 2018), to the U.S. Department of Health and Human Services (DHHS) attempt "to adopt an explicit and uniform definition of gender as determined 'on a biological basis that is clear, grounded in science, objective and administrable'" (Green et al. 2018), federal policies under Trump's leadership aimed to delegitimize transgender identity. Such efforts to curtail the rights of transgender Americans emerged in response to U.S. Department of Education (DOE) policies announced by Barack Obama's previous presidential administration that interpreted gender identity protections under Title IX (DOE 2016). ${ }^{17}$

In summer 2016, just a few months after the release of DOE's trans-affirming policy interpretation of Title IX, the national Republican Party Platform called the policy "a social and cultural revolution upon the American people by wrongly redefining sex discrimination to include sexual orientation or other categories" (RNC 2016, p. 35), foreshadowing lawmaking attempts to come. When the Trump administration came to power in January 2017, they swiftly revoked the Obama administration Title IX interpretation memo (DOE 2017).

Over the course of his administration, Trump policy makers advanced increasingly anti-trans policies. In 2018, the New York Times broke news that Trump's DHHS aimed to enforce federal policy using definitions of sex based on genetic testing and "the genitals that a person is born with" (Green et al. 2018). This explicit coupling of bodies to the legal definitions of sex became the primary tactic deployed within the wider Right-wing political movement to question the fundamental nature of transgender identity (Wuest 2019).

In 2019, unlikely alliances surfaced between conservative interest groups and selfdescribed "women's sports advocates". In April, The Heritage Foundation, a prominent conservative advocacy group, hosted a panel discussion titled, "Fair Play? Women's Athletics in the Age of Gender Identity" ${ }^{18}$ The panelists included Beth Stelzer, recent founder of a group called "Save Women's Sports" described as "a coalition that seeks to preserve biology-based eligibility standards for participation in female sports" (Stelzer 2019). Bianca Stanescu also appeared on the panel representing the interests of her daughter, Selina Soule, a cisgender high school runner from Connecticut. Each of the panelists raised explicitly transphobic concerns about "biological males who self-identify as women" competing on girls' and women's teams. ${ }^{19}$

Later that year, another conservative interest group began circulating sports-specific, anti-trans campaign advertisements in the Kentucky gubernatorial race (Peters 2019). The ads were developed by the American Principles Project (APP), an anonymously funded conservative political action committee (PAC) previously concerned with contesting samesex marriage rights and abortion (Orr 2020). The videos featured fictionalized video of wrestling ${ }^{20}$ and track ${ }^{21}$ competitions interspersed with visual screenshots of print media stories warning of dominating performances from transgender athletes. They show athletes with feminine-coded traits (e.g., long hair in a ponytail, close-fitting clothing that reveals evident breasts), who are referred to as "girls" in the voiceover, losing in competition to athletes with masculine-coded traits (e.g., short-cut hairstyle, exposed armpit hair).

17 "Gender identity", the Obama-era Dear Colleague letter read, "refers to an individual's internal sense of gender. A person's gender identity may be different from or the same as the person's sex assigned at birth;" "sex assigned at birth", it notes, "refers to the sex designation recorded on an infant's birth certificate should such a record be provided at birth" (DOE 2016, p. 1).

18 https://www.youtube.com/watch?v=etkJUCmkPfk (accessed on 24 May 2021).

19 Similar arguments would also appear in a U.S. Supreme Court amicus brief authored by the Independent Women's Forum, another conservative interest group, in the R.G E G.R. Harris Funeral Homes, Inc. v. EEOC et al. case concerning sex discrimination under Title VII (Braceras and Milanovich 2019).

20 https://www.youtube.com/watch? $\mathrm{v}=\mathrm{Qm} 1 \mathrm{gEdt106M}$ (accessed on 24 May 2021).

21 https: / / www.youtube.com/watch? $\mathrm{v}=9 \mathrm{a} 0 \mathrm{bBU} 8 \mathrm{HZm0}$ (accessed on 24 May 2021). 
The voiceover asks, "Beshear [the Democratic candidate] calls this equality, but is it fair?" (Peters 2019). The narrators prophesize a future in which girls will be "forced to compete against boys in sport". They never explicitly mention transgender athletes, hewing instead to gender-coded insinuation that transgender girls are boys, and are therefore illegitimate participants in the girl's category.

Multiple media outlets reported that APP targeted Democratic-leaning voters who they believed could be persuaded by the sports-specific anti-trans message (Orr 2020; Peters 2019). The Republican candidate, Matt Bevin, lost the race, but APP spokesperson Terry Schilling told Politico, "We wanted Bevin to win, but more than anything, we wanted to test this out before trying it at a much larger scale. Now, donors understand that although we came up a few votes short in Kentucky, this can still work. This is persuasive" (Orr 2020).

The messaging was soon pervasive. During the 2020 state legislative session-beginning only a few months after the APP debuted it in the Kentucky race-conservative lawmakers from twenty American states introduced legislation that targeted transgender athletes (Sharrow 2020b). ${ }^{22}$ My research (described fully in Section 4.1 of this paper and from which I base all descriptions of state legislative activity) finds that the first such proposals were pre-registered in New Hampshire and Tennessee in December 2019. By mid-spring, thirtytwo separate proposals had been introduced-all sponsored by Republican lawmakers. Congressionally, Republicans introduced two bills at the federal level in January (H.R. 5702 and H.R. 5603).

\subsection{Parallel Legal Challenge and State-Level Litigation}

On 12 February 2020, a conservative interest group, the Alliance Defending Freedom (ADF), filed suit in federal court on behalf of three cisgender female high school athletes. ${ }^{23}$ Selina Soule (the athlete whose mother was previously featured on the Heritage Foundation panel), Chelsea Mitchell, and Alanna Smith, all runners on girl's track teams in the state of Connecticut, were named as plaintiffs seeking a preliminary injunction to prevent two, Black transgender girls from competing in events scheduled for the 2020 Connecticut outdoor high school track season. The plaintiffs argued that existing policy of the Connecticut Interscholastic Athletic Conference (CIAC) violates Title IX, and that the cisgender runners were "being directly and negatively impacted by a new policy that is permitting boys who are male in every biological respect to compete in girls' athletic competitions if they claim a female gender identity" (Soule et al. $v$. CIAC, 2 ). ${ }^{24}$ The CIAC athletic eligibility policy permits athletes to compete in the category consistent with their gender identity. 25 The plaintiffs claimed that the "discriminatory policy is now regularly resulting in boys displacing girls in competitive track events in Connecticut-excluding specific and identifiable girls including Plaintiffs from honors, opportunities to compete at higher levels, and public recognition critical to college recruiting and scholarship opportunities that should go to those outstanding female athletes" (Soule et al. v. CIAC, 2).

By late spring 2020, the COVID-19 pandemic caused the cancellation of the Connecticut high school track season and a shortened legislative session in many states. However, just as much of the world headed into pandemic lockdown, Idaho's governor Bradley Little signed the "Fairness in Women's Sports Act" into law on 30 March. The law allowed for challenges to the eligibility of any girl or woman (cis or trans) competing in school-

22 In 2020 these include (with sports bill counts in parentheses) Alabama (2), Arizona (1), Colorado (1), Georgia (1), Idaho (1), Indiana (1), Iowa (1), Kansas (1), Kentucky (1), Louisiana (2), Massachusetts (2), Minnesota (2), Mississippi (2), Missouri (3), New Hampshire (2), Ohio (1), South Carolina (1), Tennessee (2), Washington (1), and West Virginia (2).

23 The ADF is a far-right religious organization that routinely promotes LGBTQ+ antipathy through lawsuits and draft legislation. The Southern Poverty Law Center classifies them as an extremist hate group, a designation also reserved for the Westboro Baptist Church and seven other anti-LGBTQ+ groups (SPLC 2021). ADF's long-term objective is to seek legal outcomes that allow the denial of LGBTQ+ people goods and services on the basis of religion. Their recent activity is concerned with securing legal definitions of sex as an immutable biological category, and gender as a subjectively determined identity (Wuest 2019, 2021).

24 The lawsuit followed a Title IX complaint by the athletes to the U.S. Department of Education Office for Civil Rights in August 2019.

25 Connecticut state law also prohibits discrimination on the basis of gender identity or expression in all areas where the law already protects again sex discrimination (i.e., under Title IX) (MAP 2021a). 
sponsored youth, high school, or college sports and required that any "dispute regarding a student's sex shall be resolved" by a "verification" of the "student's biological sex" (Idaho H.B. 500).

The American Civil Liberties Union (ACLU) brought suit against the state of Idaho under Title IX and the U.S. Constitution on behalf of two plaintiffs, Lindsay Hecox and Jane Doe. ${ }^{26}$ Hecox is a transgender athlete at Boise State University who wants to compete on the women's cross country team; Jane Doe is a cisgender high school soccer player. The ACLU argued that H.B. 500 is out of step with elite athletic policy (where transgender athletes are allowed to participate pending medical treatments) and prevailing norms of transgender inclusion in sports associations around the world, that it "opens the door to severe privacy violations and the forced disclosure of women's and girls' sensitive medical information (including those who are neither transgender nor intersex, among others)", and it "will cause severe and entirely unnecessary harms and distress, including to a subset of women and girls who already face exceedingly high rates of suicidality due to ongoing societal inequities caused by discrimination of the sort H.B. 500 perpetuates" (Hecox v. Little, 5). During the spring and summer of 2020, the Trump administration U.S. Department of Justice filed briefs in both the Connecticut and Idaho cases advancing an interpretation of Title IX that would not protect students from gender identity discrimination (DOJ 2020a, 2020b). ${ }^{27}$ In the midst of this, on 15 June 2020, the U.S. Supreme Court ruled in Bostock v. Clayton County, Georgia. ${ }^{28}$

The ruling in Bostock pertained not to Title IX, but to federal-level employment protections under Title VII of the Civil Rights Act of 1964 (CRA). Title VII of the CRA prohibits employment discrimination on the basis of race, color, religion, sex, or national origin (Pub. L. 88-352). At stake in the Bostock case was whether discrimination on the basis of gender identity is a form of sex discrimination. The Court ruled that LGBTQ+ peopled fired because of their sexual orientation or gender identity are protected under civil rights law (Liptak 2020). However, given that evolving definitions of sex discrimination in one domain of law (i.e., under Title VII) are less likely to be contradicted by any subsequent federal rulings on sex discrimination in another realm (i.e., Title IX), the majority also implicitly signaled for interpretations of gender identity protections more broadly.

In his dissenting opinion, Justice Samuel Alito addressed looming sports-specific anxieties, noting:

"Another issue that may come up under both Title VII and Title IX is the right of a transgender individual to participate on a sports team or in an athletic competition previously reserved for members of one biological sex. ... The effect of the Court's reasoning may be to force young women to compete against students who have a very significant biological advantage, including students who have the size and strength of a male but identify as female and students who are taking male hormones in order to transition from female to male" (Bostock v. Clayton County, 47).

The minority of dissenting justices surfaced concerns that adjudicating Title IX's protections in sports would be inextricably tied to physical bodies, echoing an argument previously articulated by the Soule et al. $v$. CIAC plaintiffs.

Despite heightened attention to gender identity protections in the aftermath of Bostock, the 2020 U.S. presidential campaign transpired without significant national focus on transgender rights from the Trump campaign. Still, the APP PAC spent $\$ 4$ million in anti-trans sports advertisements throughout the fall in Michigan, Pennsylvania, and Wisconsin (APP

26 Hecox, et al. v. Little, et al., No. 1:2020cv00184-Document 63 (D. Idaho 2020).

27 These briefs were in concordance with the stance of the Trump administration (DOE 2017) that revoked Obama administration-era transgenderinclusive protections under Title IX (DOE 2016).

28 Bostock v. Clayton County, 590 US_(2020). 
2020). ${ }^{29}$ Media reports suggested that conservatives were quietly debating whether openly attacking transgender people could constitute a winning strategy given public backlash and the expense associated with previous anti-trans campaigns in North Carolina and Virginia to restrict access to public restrooms to transgender people (Orr 2020).

At the federal level, the Trump administration remained committed to pursuing bans on transgender inclusion via their executive power. In the waning months of the administration, U.S. Secretary of Education Betsy DeVos threatened to withhold $\$ 18$ million in federal racial desegregation grants from Connecticut schools if the affected districts did not withdraw their support for trans-affirming CIAC policies (Broadwater and Green 2020). ${ }^{30}$ Denial of DOE funds in one realm to coerce policy compliance in another would have been unprecedented. ${ }^{31}$ In the U.S. Congress, lawmakers sponsored two new sports-related bills, one, in September (S. 4649) by Senator Kelly Loeffler (R-GA), and another in December 2020 (H.R. 8932), by Representatives Tulsi Gabbard (D-HI) and Markwayne Mullin (R-OK). Both called for the "protection" of sports for women and girls.

\subsection{Action in the States, 2020 and 2021}

The first month of 2021 witnessed fast-moving state legislative activity. By the end of January, nineteen bills in thirteen states proposed the exclusion of transgender girls from school-sponsored girls' sports team. ${ }^{32}$ In February, legislators filed twenty-nine additional proposals; throughout March, they proposed another nineteen. ${ }^{33}$ On March 11, 2021, the Mississippi governor became the next to sign a bill into law (S.B. 2536). Over the next two weeks, Arkansas (S.B. 354), Tennessee (S.B. 228), and South Dakota followed suit. ${ }^{34}$ In April, these states were joined by Alabama (H.B. 391), West Virginia (H.B. 3293), and Arkansas (S.B. 450, a second law addressing enforcement of the first). Governors in Montana (H.B. 112) and Florida (S.B. 1028) next signed laws in early summer. ${ }^{35}$ As of July 29, 2021, bills remain active in Wisconsin and Texas, where eight additional bills were introduced during a mid-July special session (Abbott 2021). ${ }^{36}$ All told, bills were proposed in thirty-six states in $2021 .^{37}$

Trump began to speak more openly about the issue in the concluding months of his presidency. His administration finalized additional bureaucratic rollbacks of nondiscrimination protections for LGBTQ+ people under the Affordable Care Act (DHHS 2021). On 6 January 2021, during the rally that precipitated the U.S. Capitol siege, Donald

29 By comparison, the total spending during the 2020 U.S. presidential election was over $\$ 14.4$ billion (Evers-Hillstrom 2021). Thus spending on these advertisements was comparatively small, even in Michigan where APP spent half of their money. Michigan's Senate race-the race most aggressively targeted by APP with the anti-trans advertisements—-was the eighth most expensive nationally with spending topping just over $\$ 197$ million.

30 The full record of U.S. Department of Education notification to the Connecticut districts is archived online (Office for Civil Rights in the U.S. Department of Education 2020), though the Biden administration has announced that the policy therein is inconsistent with Executive Order 13988.

31 The Biden administration has since ensured that the school districts will receive the funds.

32 An additional bill was proposed that month in the U.S. Congress (H.R. 426).

33 Republican members of the U.S. Congress introduced two additional bills in March 2021, S. 251 and H.R. 1417.

34 South Dakota's bans followed a circuitous route. Governor Kristi Noem announced a partial veto of the bill (H.B. 1217) passed by the South Dakota state legislature, citing concerns over potential lost revenue from sports championships. During the 2016-2017 collegiate athletic season, the NCAA agreed to withdraw championships from the state of North Carolina due to the passage of a state law that banned the use of public restrooms for transgender people (NCAA 2016). Governor Noem indicated that she would support a ban on participation by transgender athletes at the elementary and high school (but not collegiate) levels; efforts to over-ride her veto failed in the legislature. Noem then issued two Executive Orders which, in effect, accomplished many of the aims of the legislature's bills through her executive powers (Groves 2021).

35 In Florida, the legislators finished debate and voting on the bill in late April but then delayed sending it to Governor Ron DeSantis until the end of May, enabling him to sign the bill on June 1, the first day of LGBTQ+ Pride Month.

36 These eight special session bills in Texas, all proposed after my analyses were complete, are neither included in my study nor in the total 2021 bill counts.

37 In 2021 these include (proposed sports bill counts in parentheses) Alabama (1), Alaska (1), Arizona (1), Arkansas (3), Connecticut (3), Florida (4), Georgia (3), Hawaii (1), Illinois (1), Iowa (2), Kansas (2), Kentucky (2), Louisiana (2), Maine (2), Michigan (2), Minnesota (4), Mississippi (1), Missouri (7), Montana (1), New Hampshire (1), New Jersey (2), New Mexico (1), North Carolina (1), North Dakota (2), Ohio (2), Oklahoma (2), Pennsylvania (1), Rhode Island (1), South Carolina (3), South Dakota (1), Tennessee (2), Texas (6, not including bills proposed in July special session), Utah (1), Washington (1), West Virginia (6), and Wisconsin (4). 
Trump, Jr. delivered expletive-riddled, transphobic comments about trans athletes to the assembled crowd moments before they stormed the U.S. Capitol building (Avery 2021).

When President Joe Biden's administration assumed office in January (and as discussed at greater length in the conclusions), they issued Executive Order 13,988 requiring review of all Trump-era policies on gender identity discrimination (White House 2021). The U.S. House of Representatives also quickly moved to pass the Equality Act (a federal-level policy proposal to ban workplace discrimination against LGBTQ+ people) in February (Edmondson 2021). That same month, another high-profile advocacy group, the "Women's Sports Policy Working Group", comprised of several former Olympians and long-time Title IX advocates, published a statement advocating against the inclusion of transgender girls and women on girls' and women's sports teams (WSPWG 2021). ${ }^{38}$ Throughout late 2020 and early 2021, conservative media aired over seventy discussions about transgender athletes on Fox News (January 2021). As state legislative activity increasingly targeted the rights and bodies of transgender youth, partisan stances became demarcated.

\section{Bill Content Themes and Cis Supremacy}

The 2021 legislative session followed these precipitating events. Scholars suggest a number of possible reasons for increased legislative activity in such circumstances. After the U.S. Supreme Court decided the same-sex marriage cases, legal scholars anticipated that strategies of the political Right would shift to targeting transgender people (Minter 2017). Anti-queer causes, organizations, and activists have long found common cause with partisan forces on the Right (Schreiber 2008). It is not uncommon for shifts in partisan leadership at the federal level to render more aggressive lawmaking tactics by the minority party at the state level (Miras and Rouse 2021), and 2021 was decisively partisan. Nearly all of the eighty anti-trans sports bills were sponsored by Republican lawmakers. ${ }^{39}$

Over the past decade as some state and local governments began passing laws that explicitly affirm gender identity-based rights (see Taylor et al. 2018, 2021), conservative forces in American politics responded. Scholars note that emergence of "backlash" to civil rights victories is often related to the visibility of advocacy strategies (Gash 2015). With increased public attention to LGBTQ+ rights, including through the U.S. Supreme Court decisions on same-sex marriage, the end of "Don't Ask Don't Tell" in the U.S. military, and most recently the court decision in Bostock, the anti-trans coalition of Christian religious rights organizations and trans-exclusionary radical feminists (TERFs) began to pursue antiLGBTQ+ policies under the auspices of religious freedom (Wuest 2021) and "protecting" women. ${ }^{40}$

\subsection{Bill Identification Method and Analysis}

In order to track all sports-related bills targeting the participation of transgender athletes in the 2020 and 2021 legislative sessions, I created an original dataset of all proposed legislation by utilizing the LegiScan.com search function. LegiScan compiles information

38 The group wrote, "We ask Congress and the Administration to affirm Title IX's long-standing commitment to providing biological females with equal experiences and opportunities in competitive sport, and to protecting their safety in contact sports, by permitting recipients of federal funds to continue to operate or sponsor separate athletic teams and events for males and females" (WSPWG 2021, p. 5). Although the group described themselves as a "middle ground" on the questions of trans inclusion, the gendered language they employ align them more closely with anti-trans groups. Their congressional advocacy materials note, "We use 'female' throughout to denote a person's biological sex regardless of their gender identity. We use 'trans(gender) girl/woman' throughout to denote a person born male who identifies as a girl/woman", instead of using trans-affirming language designating sex assigned at birth (WSPWG 2021, p. 5). Members of this working group previously published a high-profile opinion piece advocating for a "carve out" from the Equality Act to prevent Title IX protections from including transgender athletes (Coleman et al. 2019).

39 The Republican Party has long championed anti-LGBTQ+ causes, having notably led the charge to ban same-sex marriage at both the federal and state levels. Only one anti-trans sports bill in Hawaii (H.B. 1304) came from the desk of a Democratic state legislator.

40 The long-standing commitment of the Religious Right to antigay politics is well documented (e.g., Critchlow 2005; Herman 1997; Lax and Phillips 2009; Self 2012), as are the consequences of such politics for targeting transgender people (Davis 2014; Murib 2020; Schilt and Westbrook 2009; Stone 2018; Westbrook and Schilt 2014). The tactics of the Religious Right have impacted much policymaking on issues of sexual and reproductive freedom. From the politics of abortion and teen pregnancy (Luker 1984, 1996), to the control of Black women's sexuality (Collins 2004; Hancock 2004; Roberts 1997), bodies, and the right to queer freedom and autonomy, remain subject to the will of lawmakers (e.g., Kurth et al. 2021). 
about proposed bills in all fifty states and in the U.S. Congress. For each state, I conducted initial searches to identify bills that addressed the participation eligibility of high school and college athletes using multiple search terms: "sex athletics", "women sports", "girl sports", "transgender". Notably, the term "transgender"—a search term deployed in other studies of anti-trans legislation (see methodology in Murib 2020)—rarely rendered results. I attribute the absence of this terminology to the aforementioned political tactics deployed by conservative groups that deny the existence of transgender people by denigrating the notion of gender identity as distinct from sex assigned at birth. Thus, I developed search terms based on the content of rhetoric used by Republican lawmakers that favored terms such as "sex", "girl" or "women" when referencing participants on athletic teams. Using LegiScan, I utilized the publicly-available search function to access complete bill text and tracking information. I began tracking bills in February 2020, including those already proposed for the 2020 legislative cycle, and monitored LegiScan for developments weekly throughout the remainder of the 2020 and the entirety of the 2021 legislative cycles. ${ }^{41}$ In order to avoid inappropriate comparisons across legislative cycles, I limit my analyses herein to only the eighty bills proposed in 2021.

I reviewed and organized each of the bills based on titles and conceptual content, the first phase of thematic analyses (Braun and Clarke 2021). I then closely read each of the bills for themes, cataloguing references to the targeted policy groups, the references to sex-based categories, the proposed structures for organizing athletic competition, proposed legal enforcement mechanisms, references and interpretation of Title IX, and explicit references to sex-based traits (e.g., hormones). As I discuss in what follows, many of the bills proposed in multiple, different states include large portions of verbatim text and identical titles. Employing a reflexive appraisal of these close readings and analyses, I organized and constructed the following themes that reflect the content of proposed legislation on the topics of interpreting Title IX/sex equity policies in sports, gendered understandings of the physical body, women's presumed physical capacities, and their relationships to state level public policy.

Of the sports-specific bills proposed in the 2021 state legislative and U.S. congressional session, all but one of them were unambiguously anti-trans (South Dakota S.B. 190 aimed to counter South Dakota H.B. 1217, an anti-trans sports bill proposed on the same day). Nearly every bill focused on high school athletics but approximately one-fifth also focused on elementary school sports teams. ${ }^{42}$ Slightly more than half also target collegiate sports. Very few of the state bills explicitly linked their purpose to challenging interpretations of Title IX, commonly referencing policy design of sex-segregated sports if the law is noted. ${ }^{43}$ Many of the bills aimed to shape new state law, although some propose state constitutional amendments, a tactic also deployed among those who contested marriage equality at the state level (see Arkansas S.J.R. 16; Missouri H.J.R. 53 and H.J.R. 56). Numerous bills share titles: "Save Women's (or/and Girl's) Sports Act" (17 bills) or the "Fairness in Women's Sports Act" (12 bills). These titles provide insight into how they are framed.

Five "cis-supremacist" themes emerged from my reading relating to protectionism, gendered hierarchy, sex-based binaries, and physical bodies. ${ }^{44}$ These buttress the espoused arguments to exclude transgender girls from sport, recurring throughout the proposed legislation to both reinforce and elevate normative ideologies of gender. The following sections illustrate how notions of "cisgender supremacy" infuse the proposed laws.

41 I also cross-referenced for accuracy these results with databases maintained by interest groups, including Equality Equality Federation (2021), during the 2021 legislative cycle.

42 There is no national sport governing body for interscholastic competition before high school (whereafter the National Federation of State High School Associations organizes the various state-level associations), when youth athletics are far more commonly organized through local/municipal athletic associations or private leagues (Messner and Musto 2016). These environments frequently present inclusion challenges for transgender and gender non-conforming children (Travers 2016).

43 The exception is for proposed congressional legislation all of which designated their intent to amend federal law.

44 Supremacist ideology asserts fixed hierarchies among dominant and subordinate groups, typically motivated by ideas about the minority group's immutable traits that are used to justify the order and retain the already empowered group/identity at the top (e.g., Canaday 2009; Novkov 2001, 2008; Soss et al. 2011). 


\subsection{Theme 1: Elevation of Sex Segregation and "Natural" Gendered Physical Hierarchies}

All of the proposed bills presume or avow the need for sex-segregated sports in schoolsponsored athletics. Although only a minority reference Title IX itself, its sex-segregated logic in policy design suffuses expectations about how athletic competition should be structured. Lawmakers advance these assumptions by conflating segregated structures with the practice of equality and by suggesting that the integrity of egalitarianism and "fair" competition is only preserved through a sex-segregated athletic system.

In many states, references to segregation are linked with the pursuit of parity, asserting that "having separate sex-specific teams furthers efforts to promote sex equality" (Kansas S.B. 55, also quoted in bills in Arkansas, Florida, Louisiana, New Hampshire, New Jersey, New Mexico Rhode Island, South Carolina, South Dakota, and West Virginia). The history of women's exclusion from athletics before the passage of Title IX lead many lawmakers to assume that segregation is the only solution to disparate treatment (a conclusion challenged by scholars critical of policy design; see McDonagh and Pappano 2007; Sharrow 2021). In Minnesota, proposed policy suggests:

"When an equal opportunity to participate in the elementary or secondary school level athletic program of an educational institution or public service is not provided to members of a sex whose overall athletic opportunities have previously been limited, that educational institution or public service shall, where there is demonstrated interest, provide separate teams for members of the excluded sex" (Minnesota H.F. 350).

In several states, lawmakers directly argue that the integrity of substantive equality relies on sex segregation. For example, lawmakers in Florida argue that, "this act, which requires the designation of separate sex-specific athletic teams, is necessary to redress past discrimination against female athletes and to avoid jeopardizing the equality of athletic opportunity in this state" (Florida S.B. 2012).

This theme illustrates how lawmakers aim to mobilize the narrowest interpretation of Title IX's segregated policy design when confronting questions of transgender inclusion. For example, state laws are proposed that would ignore nuance in long-standing federal policy (DOE 1979). Specifically, Title IX confers athletes with a right to try-out for "opposite sex" teams when their school does not offer a team that comports with their identity (see discussion in Sharrow 2021)..$^{45}$ Proposed legislation would instead protect institutions by precluding scrutiny "for maintaining separate school athletic activities for students of the female sex" (Utah H.B. 302). Such proposals intend to limit the latitude granted to athletic associations to organize competitive eligibility that meets the needs of students in their states-including those based on gender identities of their constituent athletes. This theme illustrates how proposals would escalate the practice of separate categories to a legal imperative, and contravene the limited opportunities for partially sex-integrated teams that exist in the status quo (e.g., Klecker 2019). ${ }^{46}$ Practically speaking, proposals also reject interpretations of policy that could enable the incorporation of transgender athletes without intensive and invasive gendered surveillance (i.e., allowing participation based on gender identity without need for medical interventions as allowed under aforementioned CIAC policy, and as explored in Theme 3).

The reasons articulated by lawmakers for deepening institutionalized commitment to segregation are notable because they presume the embodied inferiority of (all) girls and women as compared with (all) boys and men. For example, Alabama H.B. 391 (now law, Act 2021-285) states, "Because of the physical differences between biological males

45 See also recent caselaw [Gordon v. Jordon School District, Civil No. 2:17-cv-00677-HCN-DAO (D. Utah 1 March 2021)] with respect to football leagues who, a U.S. Circuit Court decided, must only require tryouts for girls to play on existing boy's teams, not for leagues to offer separate teams for girls (Vejar 2021).

46 There are some states, like North Dakota, that take an imbalanced approach, explicitly suggesting that while cisgender girls can try out for "boy's" teams, transgender girls cannot participate on "girl's" teams. They propose, "This section may not be construed to prohibit a female from participating in a school-sponsored athletic team or event that is exclusively for males" (North Dakota H.B. 1298). 
and biological females, having separate athletic teams based on the athletes' biological sex reduces the chance of injury to biological female athletes and promotes sex equality". Or, as Tennessee H.B. 3 (now law, Public Chapter 40) argues, "studies show that boys, on average, can be physically stronger than girls, having more skeletal muscle mass than girls and more upper-body and lower-body strength, which can result in injury to girls if girls participate in contact sports with boys". Lawmakers center age-old myths about the comparative frailty of girls and women to justify segregation (see, e.g., Dowling 2000).

Notions of physical weakness are both promoted in and buttressed by segregated structures. As I explore in Theme 2, they also employ ideas about binary sex that elevate the status of boys and men in order to subordinate women and girls. These themes co-articulate and illustrate how within current political contests over the meanings of sex and gender non-discrimination remain concerned with dubious notions of women's inherent physical weakness and of essential "male biological advantage" in all athletic pursuits. This circular logic endorses ideas about "natural" gendered hierarchies that require segregation even as the practice of segregation suppresses any evidence to the contrary.

Segregated athletics, premised on maintenance of two distinct and categorizable types of competitors, also create a mirage of presumptive cisgender status. Structural segregation rests on the belief of "real" categories of difference. Stabilizing a segregated structure is foundational to the hierarchy that values cisgender athletes over transgender athletes (even as they challenge the fixedness of gendered categories and the system that relies on them).

\subsection{Theme 2: Sex Assigned at Birth as Immutable Destiny}

This logic of segregation implicitly requires clarity over who constitutes a "woman" or a "girl", and who does not-a concern among lawmakers expressed in this second theme. The collective approach across bills is a categorical definition of "sex" narrowly conflated with sex assigned at birth. The language employed in proposed bills routinely and narrowly focuses on "biological sex" instead of gender identity, and rarely explicitly acknowledges the existence of "transgender" people who identify as such. ${ }^{47}$ Instead, transgender girls and women are regularly misgendered as "biological males". This theme, in tandem with Theme 3, illustrates how bodies are called upon to provide testimony as to their sex, described below.

Nearly every bill either directly articulates or alludes to the pressing need for "athletic teams to be designated based on biological sex" (Oklahoma S.B. 2). ${ }^{48}$ The method for designation is physiological, for example: "'Sex' means a person's immutable biological sex as objectively determined by anatomy and genetics existing at the time of birth" (Arkansas S.B. 450, now Act 953).$^{49}$ As if to underscore the point, the aforementioned Arkansas bill is named the "Gender Integrity Reinforcement Legislation for Sports (GIRLS) Act".

The dominant argument is that sex assigned at birth is determinative both for identity and for policy-based rights. Denigration of transgender identity is often rooted in questioning the legitimacy of its existence compared to designations by medical authorities made at the time of birth. This echoes the framings deployed in previous anti-trans campaigns targeting access to public restrooms (Murib 2020), public transportation and identification documents (Davis 2014), and general legislation in support of LGBTQ+ rights (Stone 2018). This theme also illustrates legislators' attempts to calcify "sex" as merely that assigned at birth in order to delegitimize gender identity as a stable or defensible category.

47 Very few proposed bills specifically reference transgender people (only 4) or employ the term "gender identity" (only 7, all in order to draw contrast to the meanings of "sex"). The four bills (in Kansas, Hawaii, Rhode Island, and West Virginia) only reference transgender people when excerpting a quote from a study.

48 Some conflate sex and gender, such as in Alabama where lawmakers write, "This bill would provide that public K-12 schools may not participate in, sponsor, or provide coaching staff for interscholastic athletic events at which athletes are allowed to participate in competition against athletes who are of a different biological gender, unless the event specifically includes both biological genders (H.B. 391, now Act 2021-285).

49 Robust critique of a unified notion of "biological sex" is well-established in scholarly literature but unacknowledged in the legislative proposals (Fausto-Sterling 2000; Karkazis 2019; Richardson 2015). 
The restrictive definitions of sex are used to misgender trans athletes by referring to transgender girls and women as "biological males". This misgendering is intentional, but subtle. Multiple bills employ the same language of designation, stating:

“DESIGNATION OF ATHLETIC TEAMS OR SPORTS-(a) Interscholastic, intercollegiate, intramural, or club athletic teams or sports that are sponsored by a public primary or secondary school, a public postsecondary institution, or any school or institution whose students or teams compete against a public school or public postsecondary institution shall be expressly designated as one of the following based on biological sex: 1 . Males, men, or boys; 2 . Females, women, or girls; or 3. Coed or mixed.(b) Athletic teams or sports designated for females, women, or girls may not be open to students of the male sex" (Florida H.B. 1475; similar language is used in bill originating in Wisconsin, West Virginia, Arkansas, New Jersey, Rhode Island, Iowa, and Montana).

These bills designate a transgender girl or woman seeking opportunity on a girl's or women's team as an illegitimate participant in the "female" category. The specific use of the terms "male" and "female" also reveal the intent of lawmakers to naturalize sex as a binary category, to disparage approaching gender identity as a continuum, and to claim only the binary understandings as a reasonable organization strategy for competitive athletics.

Implicit in the language used by lawmakers is the fixedness of sex and the consequences of sex-based traits. Numerous proposed bills make reference to "inherent differences" between women and men. Bills in twelve states selectively quote directly from the Supreme Court majority opinion in U.S. v. Virginia, the famous case that forced the Virginia Military Academy to cease the exclusion of women from their ranks. ${ }^{50}$ The bill text quotes from a passage in the opinion that asserts "inherent differences" exist "between men and women", or as other bills say "between biological males and biological females" (see Kansas S.B. 55; Louisiana H.B. 542 and S.B. 156; Arkansas S.B. 354 and S.B. 450; Florida S.B. 2012; New Jersey S. 3540 and A. 5545; New Mexico H.B. 304; Rhode Island S. 638; West Virginia H.B. 2676, H.B. 2734 and S.B. 341; Kansas S.B. 208; Montana H.B. 112; South Carolina H. 3477 and S. 531). Bill text suggests that such distinctions inhabit the physical body and "range from chromosomal and hormonal differences to physiological differences" (e.g., Arkansas S.B.354, now Act 461).

Multiple bills advance one particular argument (verbatim across bills) which suggests that the impacts of sex traits cannot be changed:

"The benefits that natural testosterone provides to male athletes is not diminished through the use of puberty blockers and cross-sex hormones. A recent study on the impact of such treatments found that even 'after 12 months of hormonal therapy', a man who identifies as a woman and is taking cross-sex hormones 'had an absolute advantage' over female athletes and 'will still likely have performance benefits' over women" (New Jersey S. 3540 and A.5545; Rhode Island S. 638; West Virginia H.B. 2676, H.B. 2734, H.B. 2917, and S.B. 341; Kansas S.B. 208 and S.B. 55; Arkansas S.B. 354).

These supposedly immutable impacts of traits comprise what one advocacy group (i.e., the aforementioned Women's Sports Policy Working Group) coined a "legacy advantage" which they describe as "the permanent or long-lived physical effects of experiencing puberty in the male body. The term refers to the considerable size and strength advantages that remain even after hormone treatments or surgical procedures" (WSPWG 2021, p. 18).

$50 \quad 518$ U.S. 515 (1996). 
Lawmakers articulate fears that some traits of bodies are fixed and unalterable. ${ }^{51}$ They erroneously suggest that transgender women are the same as cisgender men, and are and always will be "biological men".

Many also deny the relevance of gender identity considerations in determining access to athletics. For example, lawmakers in West Virginia (H.B. 3293, now §18-2-25d) note, "gender identity is separate and distinct from biological sex to the extent that an individual's biological sex is not determinative or indicative of the individual's gender identity. Classifications based on gender identity serve no legitimate relationship to the State of West Virginia's interest in promoting equal athletic opportunities for the female sex". In Arkansas, they propose that, "Members of the male sex are prohibited from an athletics, sports, or other similar activity that is expressly designated for females, women, or girls. (S.B. 450, now Act 953). Or, as they contended in Kentucky, "An athletic activity or sport designated as 'girls' shall not be open to members of the male sex" (S.B. 106).

This theme illustrates how lawmakers mobilize imprecise and partial readings of the scientific literature to craft an understanding of fixed sex at the core of segregated sports. They argue that the impacts of fixed sex on athletic performance render athletes assigned male at birth with inherent athletic superiority, and that sex assignment, once rendered, cannot be altered. These framings advance a supremacist ideology that favors cisgender associations to sex-based categories and embodied sex traits. They flatten the realities of gender-diverse bodies and falsely suggest that sex is always (and only) male or female (see, e.g., Karkazis 2008 for a critical orientation to these ideas from the perspective of intersex people).

\subsection{Theme 3: Bodies as Testimony (Genitals, Hormones, Chromosomes)}

In the socio-legal order proposed in many bills, the immutability of sex requires enforcement of policy through a sex-segregated system. This third theme illustrates how lawmakers conceptualize the administration of bodies and the categories of sex. These arguments constitute what West and Zimmerman (1987) call the "biological credentials" of participation in the sex-segregated athletic structure. Across nearly every proposed bill, lawmakers seek implementation of binary, male/female categorization through the inspection of bodily traits. Through forcible examination of children's genitals, hormones, and/or chromosomes, lawmakers suggest that bodies will reveal their "real sex".

As discussed in Theme 2, many proposals link the moment of sex assignment at birth to innate gender. Birth designations are referenced in nearly every proposal. Pennsylvania lawmakers note, "For the purpose of this act, biological sex is based solely on an individual's reproductive organs, biology or genetics at birth" (H.B. 972). Georgia officials declare: "'Gender' means a person's biological sex at birth and shall be recognized based on a person's reproductive organs at birth" (H.B. 372). Arkansas's policy designates that sex is: "objectively determined by anatomy and genetics existing at the time of birth" (S.B. 450). Medical authorities are sometimes directly named as a arbiters of sex, noting, for example, that "the bill defines 'sex' as the sex determined at birth by a physician and reflected on the birth certificate" (Wisconsin S.B. 322). Some states acknowledge how they intend to clarify any classification ambiguities resulting from identity documents, noting "a statement of a student's biological sex on the student's official birth certificate is considered to have correctly stated the student's biological sex as determined at the student's birth if the statement was: (1) entered at or near the time of the student's birth, as determined by University Interscholastic League rule; or (2) modified to correct a clerical error in the student's biological sex" (Texas H.B. 4042 and 4043). Twenty-two bills mention birth certificates as properly identifying the sex of athletes. All references relate to ferreting

51 Objectively, neither the arguments of lawmakers nor the WSPWG are supported by peer-reviewed science which concludes that there is more we don't than do know or fully understand about the impacts of hormones on athleticism (Jordan-Young and Karkazis 2019; Karkazis et al. 2012; Karkazis and Jordan-Young 2015; Roberts et al. 2021). One study directly contradicts the arguments advanced by legislators stating, "there is no direct or consistent research suggesting transgender female individuals (or male individuals) have an athletic advantage at any stage of their transition" (Jones et al. 2017, p. 701), but none of the bills acknowledge this finding. 
out possible girls and women who were assigned male at birth but seek participation in girls' /women's sport.

In some bills, lawmakers suggest the need to forgo mediating documents (e.g., birth certificates that could be updated to comport with gender identity in some states and localities) in favor of determining sex directly. Arkansas lawmakers suggest that the participation eligibility of any athletes on a sex-segregated team could be called into question (by competitors, officials, or observers) and, "If disputed, a student may establish his or her sex by presenting a signed physician's statement that shall indicate the student's sex based solely upon: (1) the student's internal and external reproductive anatomy; (2) the student's normally endogenously produced level of testosterone; and (3) an analysis of the student's genetic makeup" (Arkansas S.J.R. 16). ${ }^{52}$ In other states, lawmakers propose foregoing the involvement of medical personnel and to instead require students and their parents to sign legally binding declarations of their "sex as ascertained at or before birth in accordance with the student's genetics and reproductive biology; and that the student is not taking and has not taken, during the preceding twelve months, any performance enhancing drugs, including anabolic steroids" (South Dakota H.B. 1217)..$^{53}$ The proposed policy goes on to suggest that should "reasonable cause" arise as to the possibility that the student or parents provided "false or misleading" information as to the child's "true sex", a year-long athletic participation ban would result (South Dakota H.B. 1217). None of the proposed policies suggest any sensitivity to health information privacy laws, nor do they delineate to whom the prospective athlete or their parent(s) would need to disclose such personal information in order to obtain competitive eligibility. The proposals also fail to delineate who among the possible stakeholders (e.g., fellow competitors, coaches, other parents, teachers in the school, fans or spectators) have standing to question the gender of a child or adolescent competitor. ${ }^{54}$

As alluded to in Theme 2, many lawmakers are exceptionally concerned with investigating hormonal levels. Thirteen bills suggest the need to monitor hormones of athletes particularly testosterone, a hormone that enjoys a prized place in cultural mythologies about physical strength and capacities, as well as sexual desire and athletic skill (JordanYoung and Karkazis 2019). Over one-third of all bills (28 in total) fixate on the purported impacts of testosterone on physical strength and athletic performance, many referencing a blog post about the "battle of the sexes" published at Psychology Today to substantiate their argument (Burton 2012), and cherry-picking findings from one small-N research study of transgender members of the military.

The primary concern is specified as "endogenous" testosterone [meaning, the level of testosterone-a hormone that is present in all bodies of all genders to varying degrees (Jordan-Young and Karkazis 2019)—produced by the endocrine system within any given body]. That said, some bills also erroneously suggest the need to regulate "cross-sex hormone therapy" in youth athletes, a medical practice that is not used in youth under 18 where "puberty blockers" are the prescribed treatment (Kidd et al. 2021; Shuster 2021). ${ }^{55}$ Generally speaking, the bills suggest a notable lack of engagement with the complexities of scientific knowledge about the relationship among hormones, sex, and performance (see discussion in Roberts et al. 2021). ${ }^{56}$ Lawmakers disregard the entire robust literature on the

52 Precisely the same text appears in New Jersey S. 3540 and A.5545; Ohio S.B. 132 and H.B. 61; Rhode Island S. 638; West Virginia H.B. 2676, H.B. 2734, H.B. 2917 and S.B. 341; Arizona S.B. 1637; Iowa H.F. 184 and H.F. 334; and Mississippi S.B. 2536. Similar processes of verifying anatomy, hormones and genetics are outlined in Maine L.D. 926; Florida H.B.1475; Kansas S.B. 208; and Minnesota H.F. 352 and S.B. 2536.

53 The reference to performance enhancing drugs illustrates the common misperception that gender-affirming health care in the form of pubertyblockers or hormone therapies are no different than anabolic steroids, a position that the International Olympic Committee explicitly rejects.

54 Such invasive questions aimed at gender non-conforming girls are not uncommon, as anecdotal news reports have revealed in recent years (e.g., Koss 2017; Mele 2017).

55 See Missouri H.B. 1045 and H.B. 1077, in particular.

56 Much is unknown about athletic performance among transgender athletes. Many studies have a small sample size and trans athletes are rarely included as participants. To the extent that peer-reviewed research has studied trans athletes, they have been more to study elite-level performance and not average youth. The resulting scientific knowledge is biased by specific research designs and often ignores important economic, contextual and cultural impacts on athletic performance. 
complex nature of sex itself (e.g., Fausto-Sterling 2000; Fine 2010, 2017; Jordan-Young 2010; Jordan-Young and Karkazis 2019; Richardson 2015). ${ }^{57}$

Particularly notable are the bills that recommend investigating the "reproductive anatomy" (i.e., external genitalia) of children in order to assign them access to a sports team. These tactics reveal both brazen disregard to the possibilities for sexual trauma that such examinations can exact, but also latent transphobia (i.e., the concept which describes feelings of "emotional disgust towards individuals who do not conform to society's gender expectations"; see Hill and Willoughby 2005, p. 533). The targeting of transgender girls and women is notable in this regard, particularly because of the established relationships among transphobia, genitalia, and disgust emotions (see Miller et al. 2017). Rhetorics of disgust often fixate on genitalia of transgender people (particularly women) and have historically been deployed to stoke gender panics that expose trans women to undue surveillance and even physical violence (e.g., Westbrook and Schilt 2014). The expressed desire by lawmakers to require children and adolescent bodies themselves to testify to their "real sex" suggests the veiled assumptions about "proper" bodies and the need to expel those that are deemed unworthy from a cis-centric world. They also reveal the emergence of desired surveillance of and tactics for retribution toward any athletes, parents, or school authorities who support or affirm transgender youth (further explored in Theme 5).

\subsection{Theme 4: Emphasis on "Protecting" Girl's and Women's Sport}

These tactics reveal the techniques that maintain a binary gendered order in sports, built on women's subordination and the expulsion of non-normative bodies. Research on public opinion and transgender rights reveals a strong relationship between moral traditionalist attitudes and the inclusion of transgender people in sports and beyond (Flores et al. 2020; Jones et al. 2018; Taylor et al. 2018). These "traditionalist" attitudes also illustrate how these bill aim to establish and enshrine cisgender, heterosexual orientation as the predumptive gendered order, a dimension revealed in Theme 4.

This theme links the structures, tactics, and hierarchies expressed in proposed laws to the purported purpose: the need to "save" or "protect" sports for cisgender girls and women from transgender women and girls. Every bill focused at least in part on policing the category of sports participation historically designated for girls or women. As noted above, 17 bills employ titles that illustrate this framing (i.e., "Save Women's Sports"); others have titles like the "Safety and Opportunity for Girls Act of 2021" (U.S. Congress H.R. 1417), the "Protection of Women and Girls in Sports Act of 2021" (U.S. Congress S. 251 and H.R. 426), or the "Gender Integrity Reinforcement Legislation for Sports (GIRLS) Act" (Arkansas S.B. 450, now Act 953). These names elucidate how lawmakers aim to characterize the categories of "girls" and "women" as synonymous with cisgender identity and embodied sex characteristics. Many, but not all bills mention Title IX and the longer struggle for women's inclusion in sport, suggesting that expelling and excluding transgender girls and women from women's competition should be key objectives for the next phase of policy struggle.

This theme reveals contentions that trans girls and women possess unfair advantages compared to cisgender athletes in the women's category. Such framing is not entirely new (see Fausto-Sterling 2000), as trans-exclusionary interests have long insinuated "questions" regarding the "fairness" of transgender athletes competing against cisgender athletes (Cavanagh and Sykes 2006; Westbrook and Schilt 2014). This framing implies that cisgender girls and women are the only genuine heirs to "women's sports", operating with Theme 2 to suggest that the inherent disadvantage of girls and women in sport stems from their inadequate physical capacities as compared to men and boys. Such ideas that women and

57 Specifically, the state of scientific knowledge regarding the relationship hormones and athleticism is complex and inconclusive. Studies suggest multiple factors that contribute to athleticism (Brutsaert and Parra 2006; Guth and Roth 2013). Sporting ability is determined by a range of characteristics, including aerobic and cardiac capacity, body size, mass and flexibility, and blood oxygenation abilities to name a few (Karkazis et al. 2012; Ranković et al. 2010; Tucker and Collins 2012). Non-embodied factors also play a major role in determining athletic performance, including socioeconomic indicators that determine access to training, coaching, and nutrition (Bernard and Busse 2004). 
girls need "protection" from boys and men are common in sports (Fields 2005; Sharrow 2017), and are buttressed by segregated systems (McDonagh and Pappano 2007; see also Theme 1).

Much like how anti-trans bathroom bills relied on baseless, concocted threats of phantom sexual predators in women's restrooms (Schilt and Westbrook 2015), the need for women's sports to be "protected" from transgender athletes is a dubious claim. None of the bills present evidence of transgender athletes competing in their states (much less "harming" girls or women in the process). In most states, lawmakers have been unable to identify how many transgender girls currently participate in school-sponsored athletics (Crary and Whitehurst 2021). Only in Connecticut, where the ADF lawsuit targeted to Black, trans athletes, are the athletes named. This specific instances underscores the relationship between protectionist impulses and racial threat. Racist stereotypes of Black (male) innate superiority in sport operate as subtext to the legislation proposed in 2021 where lawmakers implicitly draw upon the tropes associated with the two high-profile high school trans competitors.

Some bills suggest that transgender athletes threaten the segregated system itself, stating that the purpose of the bills is "to provide protection for any school or institution of higher education that maintains separate athletic teams or sports for students of the female sex" (Mississippi S.B. 2536, now law). Yet, the terms "transgender" or "gender identity" are scarcely mentioned with lawmakers more routinely designating "women" or "girls" as distinct from "biological males" (the term used to routinely misgender transgender girls and women; see Theme 2).

Thus, this theme also operates as a key element of system justification for the cisgender order. It illustrates how conservative lawmakers aim to re-write history of women's inclusion in sport-a history in which many conservative lawmakers and political entities have often figured as spoilers to feminist causes (Cahn 1995; Sharrow 2020a; Ware 2011). While Title IX has increasingly found political support across the partisan divide (Sharrow et al. 2018; YouGov 2017), Republican lawmakers' claims to be representatives of "protecting" women's rights are thinly supported by history. Instead, the proposed legislation more squarely reveals the desire to "protect" gendered norms that favor cisgender identity and subordinate women and girls in an androcentric world. Such framing echoes calls to "save the children", the famous anti-queer tactic utilized by Anita Bryant in the 1970s (Schreiber 2008; Self 2012). The alliance of Concerned Women for American (CWA) - Bryant's longstanding anti-feminist advocacy organization-with several lawmakers who claim to have introduced legislation to "protect female athletes" further reveals these linkages. ${ }^{58}$

\subsection{Theme 5: Victims and Offenders, Applying Tactics of Criminality}

Finally, Theme 4 operates in tandem with fabricated narratives about cisgender women's victimization by transgender people-ideas that comprise Theme 5. In both proposed legislation and public discourse advanced by those who stand against the inclusion of transgender athletes, there is abundant concern about the physical domination of cisgender girls and women by transgender girls and women in athletic competitionsomething that is referred to as "male dominance" (a framing that misgenders trans girls and women) among detractors of trans inclusion (e.g., see Coleman et al. 2019). These fears rely on the presumed defenselessness and frailty of girls and women, are underscored by the ideologies of women's weaknesses compared with men, and deploy transphobic discourses that suggest transgender women are invaders in spaces where they do not belong. These echo the false threats of sexual predation used in debates over trans access to public restrooms and apply them more narrowly to sport (Schilt and Westbrook 2015; Westbrook and Schilt 2015). This theme illustrates how lawmakers establish a false victim/offender

58 Specifically, the CWA Legislative Action Committee website archives their efforts to impact anti-trans legislation, naming lawmakers in Florida and Utah as co-signatories to their cause (CWALAC 2021) and touting their letter of support for these proposals (Nance 2021). 
discourse to justify exclusion and penalize those who might undermine the gendered status quo.

The consequences and brutality of purpose among some lawmakers are revealed in the proposed tactics for legal enforcement. In several states, criminal penalties are proposed for individuals-many of whom would be underage when competing in interscholastic athletics-who violate the laws. One especially egregious example is from Minnesota, where lawmakers propose that "... in no case may students of the male sex try out for or participate on a female-only team. A male student who participates on a female-only team is guilty of a petty misdemeanor" (Minnesota H.F. 1657). ${ }^{59}$

In West Virginia, H.B. 2141 articulates a particularly cynical orientation. Authors of the bill dedicated nearly 100 lines of text to specifying what should happen if required birth records are found to be "intentionally falsified" or "manipulated" (language used to denigrate identification documents updated to comport with a transgender person's gender identity). Not only do lawmakers propose that any schools found in possession of "falsified" birth records for (presumedly transgender) students shall be "immediately ineligible to continue to receive public funds of any type from this state or a local government", they stipulate that:

"The Attorney General shall bring a civil action in circuit court against a state or local official who willfully and intentionally commits an act that violates, or that is designed or intended to violate or frustrate, this section, and may bring a civil action in circuit court against any person who intentionally falsifies any genetic testing required ... In conducting a trial ... the court shall conduct the trial in the same manner as the court would conduct a criminal trial" (West Virginia H.B. 2141).

This reveals the impulse among lawmakers not merely to "protect" those who they frame as victims, but also to expand and promote carceral logics in order to do so. Such logics reveal the implicit stakes of transgender inclusion for those whose sense of cis supremacy are violated by it. Exclusionary tactics supported by laws that criminalize those who defy them are core mechanisms in the maintenance of supremacist orders. Whether through anti-miscegenation laws (Novkov 2008), Jim Crow segregation laws (Kruse 2005), or racist drug laws (Murakawa 2014), punitive legal arrangements are key to enforcing and maintaining supremacist orders. Though the heteropatriarchal order is reinforced and maintained through different (though interconnected) methods from those used to preserve the American racial order, the application of carceral logics to cis-supremacist logics in these bills should be taken seriously. The thematic emergence of a victim/offender enforcement rationale underscores the aggressive intent of lawmakers. Instead of framing their purpose in adjudicating competing concerns across disparate groups, they envision the strict and punitive enforcement of exclusionary principles to achieve their aims. The proposed system rests on brute prosecution of transgender athletes, their parents, or administrators who aim to facilitate their participation in school sports. The instinct to frame cisgender girls as inherent victims of "male domination" by participation of either cisgender boys or transgender girls on "girl's" teams while punishing (including by misgendering them as boys) only transgender girls who seek entrance to a segregated system is craven in its need to protect cisgender categories. Penalizing those who violate them is a central tenet of their proposed gender order.

\section{Discussion}

As the state legislative session concludes in most states, the fates of transgender athletes hang in the balance. The ACLU is pursuing litigation against states that have passed anti-trans legislation (the first two of which were filed in late May contesting a medical care ban in Arkansas and a sports ban in West Virginia; a federal court blocked

Misdemeanor and felony criminal penalties (for youth and their parents who seek gender affirming care) were also proposed in multiple anti-trans health care restriction bills (see Equality Federation 2021). 
the enforcement of the West Virginia ban on 21 July). ${ }^{60}$ Activity at the federal level has also accelerated during the first half of 2021. Among the first presidential acts of his administration, President Joe Biden issued Executive Order (E.O.) 13988 on 20 January 2021, which instructed all federal agencies with administrative responsibilities to implement sex discrimination policies to review existing procedures. The E.O. indicated the intent of his administration "to prevent and combat discrimination on the basis of gender identity or sexual orientation, and to fully enforce Title VII and other laws that prohibit discrimination on the basis of gender identity or sexual orientation" (White House 2021). ${ }^{61}$ In June, the DOE announced new policy interpretations of Title IX to these ends that reinstated Obama-era protections for transgender students (DOE 2021). In Congress, the House moved swiftly in late February to pass the 2021 Equality Act, a bill that would extend civil rights protections to prohibit discrimination on the basis of sexual orientation and gender identity by amending the Civil Rights Act of $1964 .{ }^{62}$ In April, the Connecticut District Court dismissed the Soule case that aimed to ban gender identity inclusive policies in the state. In some states where bills advanced to the governor's desk, governors issued vetoes (including on Kansas S.B. 55; Louisiana S.B. 156; and North Dakota H.B. 1298; South Dakota H.B. 1217 was temporarily vetoed but then passed via Executive Order, see footnote 34). Most other bills (excepting those still alive at the time of this paper's publication) died at the conclusion of the state legislative session.

Although the U.S. Supreme Court decision in Bostock v. Clayton County is reason for optimism among those who seek more expansive protections of sex non-discrimination law, there remains a clear need to grapple with the legacies of policy design, particularly in light of the expressed desires of Republican state lawmakers to test the extent of the ruling, possibly in future legislative sessions. The absence of affirming policymaking leaves LGBTQ+ people vulnerable to the whims of conservative lawmakers, presidents, and the courts (Bishin et al. 2020). The patchwork status quo exclusion of transgender people from sports makes them vulnerable to additional legislative and discursive attacks. ${ }^{63}$ More generally, the politics of the body have long been of central interest to conservative causes insofar as they historically target reproductive liberty and sexual autonomy (e.g., Luker 1984, 1996; Self 2012). While this most recent round of attacks on transgender people is, in many ways, an extension of previous attempts to isolate and stigmatize trans people, it is also notable in new and telling ways. These laws target the rights of trans children, thereby working to seek gendered regulation among youth in a generation that is increasingly gender diverse (Meadow 2018; Travers 2018).

Recently, a 2017 Human Rights Campaign Foundation report found that while sixtyeight percent of young people participate in organized sports, only twelve percent of transgender girls do (Johnson et al. 2018). This means that under the status quo, transgender students are less likely to reap the rewards of athletic participation, which include improved academic performance, better physical and mental health, meaningful and even life-changing social ties, and other benefits that help build healthy and fulfilling lives (Easterlin et al. 2019; Paluck and Clark 2020; Staurowsky et al. 2015). Looming enforcement of prohibitions against transgender athletes, many of which will begin implementation in summer 2021 unless or until litigation challenges are successful, not only deny them

60 B.P.J. et al. v. West Virginia State Board of Education et al., Civil Action 2:21-cv-00316 (S.D.W. Va. Jul. 21, 2021); Brandt et al. v. Rutledge et al., 4:21-cv-00450 (E.D. Ark.)

61 Throughout the spring, executive agencies began announcing their policy interpretations in response to the Biden E.O. The U.S. Department of Justice announced their intent to produce policy guidelines under Title IX that would restore gender identity protections (DOJ 2021).

62 In 2019, the U.S. House had previously passed a similar version of the same bill. In fact, different versions of the legislation have been proposed in every Congress since 1974. The inclusion of gender identity protections for transgender Americans is more recent, and has proven to be politically contentious even among Democrats (Vitulli 2010). The Senate Judiciary Committee held a hearing on the act in March; much of the testimony, particularly from witnesses invited by Republican Senators, focused on contesting gender identity protections in sport (U.S. Congress 2021).

63 For example, at the 2021 meeting of the Conservative Political Action Conference (CPAC), Trump's speech foregrounded the same anti-trans messaging used across legislative efforts. He stated "Joe Biden and the Democrats are even pushing policies that would destroy women's sports. Young girls and women are in sets that they are now being forced to compete against those who are biological males" (Weigel 2021). 
athletic participation opportunities but also the possibilities to parlay skills learned therein to the rest of their lives.

This is especially crucial for transgender youth who are commonly harassed and excluded at school (GLSEN 2017). Involvement in sports can mitigate the vulnerabilities often experienced by trans kids (Goldberg 2021). In addition to improving trans students' lives (Trevor Project 2020), the relationships built through sports teams can also facilitate a reduction in transphobia and anti-trans bias among cisgender athletes (Broockman and Kalla 2016; Kalla and Broockman 2020) Thus, the targeting of trans kids' participation in sports is an affront not only to the rights of kids at school, but also a mechanism through which expansive understandings of gender identity can be normalized even among cisgender peers.

As the fates of lawsuits contesting the policies signed by governors hang in the balance, scholarly, legal, and public opinion largely oppose the tactics of lawmakers. Major medical professional associations (Turban et al. 2021), nearly every major women's rights group (NWLC 2020), the largest women's sports advocacy organization (WSF 2021), and scores of professional and collegiate athletes (Kliegman 2021; Lamba Legal Defense and Education Fund 2020; West 2020) have come out against attempts to ban transgender girls and women from sport. Average Americans are also largely opposed to legislation of this type (Loffman 2021). The use of lawmaking bodies to contradict public will in promoting these policies is also, therefore, contestable and likely politically unsettled.

In the interim, the bodies of transgender girls and women, particularly those of color who have been already targeted by racialized surveillance of gender non-normativity (see Gill-Peterson 2018; Snorton 2017) are increasingly subjected to surveillance, scrutiny, and possible exclusion. Foundationally, this analysis demonstrates how embodied politics of women's rights in sport remain fraught a half-century after the passage of Title IX. In current political contests over interpreting the contemporary meanings of sex and gender non-discrimination, a focus on the question of transgender inclusion in sport illustrates that contemporary debates over women's rights remain concerned with dubious notions of cisgender supremacy as expressed in ideas about women's inherent physical weakness and essential "male biological advantage" in all athletic pursuits. Contemporary framings in proposed legislation intentionally misdirect public conversation from the civil rights context of Title IX and toward transphobic discourse. They also elevate a hierarchical order that privileges cisgender athletes while also protecting an increasingly outdated status quo. Ultimately, they call into question the future of gender non-discrimination policy, and its thorny entanglements with the struggle for full equality, in an increasingly complex but durably heteropatriarchal world.

Funding: This research received no external funding.

Conflicts of Interest: The author declares no conflict of interest.

\section{References}

\section{Archival Sources}

Alabama H.B. 391 (2021).

Alaska S.B. 140 (2021).

Arizona S.B. 1637 (2021).

Arkansas S.B. 354 (2021).

Arkansas S.B. 450 (2021).

Arkansas S.J.R. 16 (2021).

Connecticut H.B. 5795 (2021).

Connecticut H.B. 6128 (2021).

Connecticut S.B. 324 (2021).

Florida H.B. 935 (2021).

Florida H.B. 1475 (2021).

Florida S.B. 1028 (2021).

Florida S.B. 2012 (2021). 
Georgia H.B. 276 (2021). Georgia H.B. 372 (2021). Georgia S.B. 266 (2021). Hawaii H.B. 1304 (2021). Idaho H.B. 500 (2020). Illinois H.B. 4082 (2021). Iowa H.F. 184 (2021).

Iowa H.F. 334 (2021).

Kansas S.B. 55 (2021).

Kansas S.B. 208 (2021).

Kentucky H.B. 471 (2021).

Kentucky S.B. 106 (2021).

Louisiana H.B. 542 (2021).

Louisiana S.B. 156 (2021).

Maine L.D. 926 (2021).

Maine L.D. 1401 (2021).

Michigan H.B. 5082 (2021).

Michigan S.B. 218 (2021).

Minnesota H.F. 350 (2021).

Minnesota H.F. 352 (2021).

Minnesota H.F. 1657 (2021).

Minnesota S.F. 96 (2021).

Mississippi S.B. 2536 (2021).

Missouri H.B. 1077 (2021).

Missouri H.B. 1045 (2021).

Missouri H.B. 1184 (2021).

Missouri H.J.R. 53 (2021).

Missouri H.J.R. 56 (2021).

Missouri S.B. 9 (2021).

Missouri S.B. 503 (2021).

Montana H.B. 112 (2021).

New Hampshire H.B. 198 (2021).

New Jersey A. 5545 (2021).

New Jersey S. 3540 (2021).

New Mexico H.B. 304 (2021).

North Carolina H.B. 358 (2021).

North Dakota H.B. 1298 (2021).

North Dakota H.B. 1476 (2021).

Ohio H.B. 61 (2021).

Ohio S.B. 132 (2021).

Oklahoma S.B. 2 (2021).

Oklahoma S.B. 331 (2021).

Pennsylvania H.B. 972 (2021).

Rhode Island S. 638 (2021).

South Carolina H. 3477 (2021).

South Carolina H. 4153 (2021).

South Carolina S. 531 (2021).

South Dakota H.B. 1217 (2021).

South Dakota S.B. 190 (2021).

Tennessee H.B. 3 (2021).

Tennessee S.B. 228 (2021).

Texas H.B. 1458 (2021).

Texas H.B. 3455 (2021).

Texas H.B. 4042 (2021).

Texas H.B. 4043 (2021).

Texas S.B. 29 (2021).

Texas S.B. 373 (2021).

Utah H.B. 302 (2021).

Washington H.B. 1556 (2021). 
West Virginia H.B. 2141 (2021).

West Virginia H.B. 2676 (2021).

West Virginia H.B. 2734 (2021).

West Virginia H.B. 2917 (2021).

West Virginia H.B. 3293 (2021).

West Virginia S.B. 341 (2021).

Wisconsin A.B. 195 (2021).

Wisconsin A.B. 196 (2021).

Wisconsin S.B. 322 (2021).

Wisconsin S.B. 323 (2021).

Protection of Women and Girls in Sports Act of 2020, S. 4649, 116th Cong. (2020).

Protection of Women and Girls in Sports Act of 2020, H.R 5702, 116th Cong. (2020).

Protection of Women and Girls in Sports Act of 2020, H.R 5603, 116th Cong. (2020).

Protect Women's Sports Act of 2020, H.R. 8932, 116th Cong. (2020).

Protection of Women and Girls in Sports Act of 2021, H.R. 426, 117th Cong. (2021).

Safety and Opportunity for Girls Act of 2021, H.R. 1417, 117th Cong. (2021).

Protection of Women and Girls in Sports Act of 2021, S. 251, 117th Cong. (2021).

\section{Published Sources}

Abbott, Greg. 2021. Governor Abbott Announces Special Session Agenda; Austin: Office of the Texas Governor. Available online: https://gov.texas.gov/news/post/governor-abbott-announces-special-session-agenda (accessed on 9 July 2021).

American Priciples Project (APP). 2020. APP Announces \$4M Swing State Ad Blitz Hitting Biden and Dems for Transgender Radicalism. Available online: https:/ / americanprinciplesproject.org/elections/app-announces-4m-swing-state-ad-blitz-hitting-biden-anddems-for-transgender-radicalism/ (accessed on 15 May 2021).

Avery, Dan. 2021. Donald Trump Jr. Slammed Transgender Athletes at Rally before D.C. Riots. NBC News. Available online: https: //www.nbcnews.com/feature/nbc-out/donald-trump-jr-slammed-transgender-athletes-rally-d-c-riots-n1253377 (accessed on 8 May 2021).

Beauchamp, Toby. 2019. Going Stealth: Transgender Politics and U.S. Surveillance Practices. Durham: Duke University Press.

Bernard, Andrew B., and Meghan R. Busse. 2004. Who Wins the Olympic Games: Economic Resources and Medal Totals. Review of Economics and Statistics 86: 413-17. [CrossRef]

Bishin, Benjamin G., Justin Freebourn, and Paul Teten. 2020. The Power of Equality? Polarization and Collective Mis-Representation on Gay Rights in Congress, 1989-2019. Political Research Quarterly. [CrossRef]

Braceras, Jennifer C., and Anita Y. Milanovich. 2019. Brief of Amici Curiae Independent Women's Forum and 1013 Athletes and Parents Supporting Petitioner. Available online: https://www.supremecourt.go-v/DocketPDF/18/18-107/113275/20190822155015105 _FemaleAthleteAmicusBrief.pdf (accessed on 24 May 2021).

Brake, Deborah. 2010. Getting in the Game: Title IX and the Women's Sports Revolution. New York: NYU Press.

Braun, Virginia, and Victoria Clarke. 2012. Thematic Analysis. In APA Handbook of Research Methods in Psychology, Vol 2: Research Designs: Quantitative, Qualitative, Neuropsychological, and Biological. Edited by Harris Cooper, Paul M. Camic, Debra L. Long, A.T. Panter, David Rindskopf and Kenneth J. Sher. Washington, DC: American Psychological Association, pp. 57-71.

Braun, Virginia, and Victoria Clarke. 2021. Conceptual and Design Thinking for Thematic Analysis. Qualitative Psychology. [CrossRef]

Broadwater, Luke, and Erica L. Green. 2020. DeVos Vows to Withhold Desegregation Aid to Schools Over Transgender Athletes. New York Times. Available online: https://www.nytimes.com/2020/09/18/us/transgender-students-betsy-devos.html (accessed on 8 May 2021).

Broockman, David, and Joshua Kalla. 2016. Durably Reducing Transphobia: A Field Experiment on Door-to-Door Canvassing. Science 352: 220-24. [CrossRef]

Brutsaert, Tom D., and Esteban J. Parra. 2006. What Makes a Champion? Explaining Variation in Human Athletic Performance. Respiratory Physiology and Neurobiology 151: 109-23. [CrossRef]

Burton, Neel. 2012. The Battle of the Sexes. Psychology Today Blog. Available online: https://www.psychology-today.com/us/blog/ hide-and-seek/201207/the-battle-the-sexes (accessed on 8 May 2021).

Buzuvis, Erin. 2019. Attorney General v. MIAA at Forty Years: A Critical Examination of Gender Segregation in High School Athletics in Massachusetts. Texas Journal on Civil Liberties E Civil Rights 25: 1-37.

Buzuvis, Erin. 2021. Law, Policy, and the Participation of Transgender Athletes in the United States. Sport Management Review 24: 439-51. [CrossRef]

Cahn, Susan. 1995. Coming on Strong: Gender and Sexuality in Twentieth-Century Women's Sport. Cambridge: Harvard University Press.

Canaday, Margot. 2009. The Straight State: Sexuality and Citizenship in Twentieth-Century America. Princeton: Princeton University Press.

Cavanagh, Sheila, and Heather Sykes. 2006. Transsexual Bodies at the Olympics: The International Olympic Committee's Policy on Transsexual Athletes at the 2004 Athens Summer Games. Body E Society 12: 75-102. 
Coleman, Doriane Lambelet, Martina Navratilova, and Sanya Richards-Ross. 2019. Opinion: Pass the Equality Act, but Don't Abandon Title IX. Washington Post. Available online: https://www.washingtonpost.com/opinions/pass-the-equality-act-butdont-abandon-title-ix/2019/04/29/2dae7e58-65ed-11e9-a1b6-b29b90efa879_story.html (accessed on 8 May 2021).

Collins, Patricia Hill. 2000. Black Feminist Thought: Knowledge, Consciousness, and the Politics of Empowerment. New York: Routledge.

Collins, Patricia Hill. 2004. Black Sexual Politics: African Americans, Gender, and the New Racism. New York: Routledge.

Concerned Women for American Legislative Action Committee (CWALAC). 2021. Action Center: Save Women's Sports. Concerned Women for America. Available online: https:// concernedwomen.org/protect-female-athletes/ (accessed on 21 May 2021).

Cooky, Cheryl, La Toya D. Council, Maria A. Mears, and Michael A. Messner. 2021. One and Done: The Long Eclipse of Women's Televised Sports, 1989-2019. Communication and Sport 9: 347-71. [CrossRef]

Crary, David, and Lindsay Whitehurst. 2021. Lawmakers Can't Cite Local Examples of Trans Girls in Sports. Associated Press. Available online: https:/ /apnews.com/article/lawmakers-unable-to-cite-local-trans-girls-sports-914a982545e943ecc1e265e8c41042e7 (accessed on 30 April 2021).

Crenshaw, Kimberle. 1989. Demarginalizing the Intersection of Race and Sex: A Black Feminist Critique of Antidiscirmination Doctrine, Feminist Theory and Antiracist Politics. The University of Chicago Legal Forum 39: 139-68.

Critchlow, Donald T. 2005. Phyllis Schlafly And Grassroots Conservatism: A Woman's Crusade. Princeton: Princeton University Press.

Cunningham, George, Erin Buzuvis, and Chris Mosier. 2018. Inclusive Spaces and Locker Rooms for Transgender Athletes. Kinesiology Review 7: 365-74. [CrossRef]

Davis, Alexander K. 2020. Bathroom Battlegrounds: How Public Restrooms Shape the Gender Order. Princeton: Princeton University Press.

Davis, Heath Fogg. 2014. Sex-Classification Policies as Transgender Discrimination: An Intersectional Critique. Perspectives on Politics 12: 45-60. [CrossRef]

Davis, Heath Fogg. 2018. Why the 'Transgender' Bathroom Controversy Should Make Us Rethink Sex-Segregated Public Bathrooms. Politics, Groups, and Identities 6: 199-216. [CrossRef]

DeLaCretaz, Britni. 2021. Living Nonbinary in a Binary Sports World. Sports Illustrated. Available online: https://www.si.com/wnba/ 2021/04/16/nonbinary-athletes-transgender-layshia-clarendon-quinn-rach-mcbride-daily-cover (accessed on 1 July 2021 ).

Dowling, Colette. 2000. The Frailty Myth: Women Approaching Physical Equality. New York: Random House Publishing Group.

Easterlin, Molly C., Paul J. Chung, Mei Leng, and Rebecca Dudovitz. 2019. Association of Team Sports Participation with Long-Term Mental Health Outcomes among Individuals Exposed to Adverse Childhood Experiences. JAMA Pediatrics 173: 681-88. [CrossRef]

Eckes, Suzanne. 2021. Sex Discrimination in Schools: The Law and Its Impact on School Policies. Laws 10: 34. [CrossRef]

Edmondson, Catie. 2021. House Passes Sweeping Gay and Transgender Equality Legislation. New York Times. Available online: https:/ / www.nytimes.com/2021/02/25/us/politics/house-equality-act-gay-rights.html (accessed on 8 May 2021).

Equality Federation. 2021. Anti-Transgender Legislation. Available online: https:/ /www.equalityfederation.org/equality-tracker/ anti-transgender/ (accessed on 15 July 2021).

Evers-Hillstrom, Karl. 2021. Most Expensive Ever: 2020 Election Cost \$14.4 Billion. Open Secrets, Center for Responsive Politics. Available online: https:/ / www.opensecrets.org/news/2021/02/2020-cycle-cost-14p4-billion-doubling-16/ (accessed on 8 May 2021).

Fausto-Sterling, Anne. 2000. Sexing the Body: Gender Politics and the Construction of Sexuality. New York: Basic Books.

Fields, Sarah. 2005. Female Gladiators: Gender, Law, and Contact Sport in America. Champaign: University of Illinois Press.

Fine, Cordelia. 2010. Delusions of Gender: How Our Minds, Society, and Neurosexism Create Difference. New York: W.W. Norton.

Fine, Cordelia. 2017. Testosterone Rex: Myths of Sex, Science, and Society. New York: W.W. Norton.

Fishel, Andrew, and Janice Pottker. 1977. National Politics and Sex Discrimination in Education. Lexington: Lexington Books.

Flores, Andrew R., Donald P. Haider-Markel, Daniel C. Lewis, Patrick R. Miller, Barry L. Tadlock, and Jami K. Taylor. 2020. Public Attitudes about Transgender Participation in Sports: The Roles of Gender, Gender Identity Conformity, and Sports Fandom. Sex Roles 83: 382-98. [CrossRef]

Gash, Alison. 2015. Below the Radar: How Silence Can Save Civil Rights. New York: Oxford University Press.

Gill-Peterson, Jules. 2018. Histories of the Transgender Child. Minneapolis: University of Minnesota Press.

GLSEN. 2017. Separation and Stigma: Transgender Youth and School Facilities. Available online: https://www.glsen.org/sites/ default/files/2020-06/SeparationandStigma-FullReport.pdf (accessed on 21 May 2021).

GLSEN. 2021. Gender Affirming and Inclusive Athletics Participation: Issue Brief. Available online: https://www.glsen.org/sites / default/files/2021-05/GLSEN_Transathlete_Policies_Issue_Brief-05-03-21.pdf (accessed on 8 May 2021).

Goldberg, Michelle. 2014. What Is a Woman? The New Yorker. Available online: https://www.newyorker.com/magazine/2014/08/04 /woman-2 (accessed on 8 May 2021).

Goldberg, Shoshana K. 2021. Fair Play: The Importance of Sports Participation for Transgender Youth. Available online: https: // www.americanprogress.org/issues/lgbtq-rights/reports/2021/02/08/495502/fair-play/ (accessed on 1 March 2021).

Green, Erica L., Katie Benner, and Robert Pear. 2018. 'Transgender' Could Be Defined Out of Existence Under Trump Administration. New York Times. Available online: https:/ / www.nytimes.com/2018/10/21/us/politics/transgender-trump-administration-sexdefinition.html (accessed on 8 May 2021).

Griffin, Pat, and Helen Carroll. 2011. NCAA Inclusion of Transgender Student-Athletes. Indianapolis: National Collegiate Athletic Association. Available online: https://docs.wixstatic.com/ugd/2bc3fc_44693cb5d779311cabc005d959e9486d.pdf (accessed on 1 June 2021). 
Groves, Stephen. 2021. South Dakota Governor Kills Transgender Bill, but Orders Ban. Associated Press. Available online: https: / / apnews.com/article/legislature-south-dakota-legislation-kristi-noem-bills-59127fe856b9727300bd9264d9a38eff (accessed on 8 May 2021).

Guth, Lisa, and Stephen Roth. 2013. Genetic Influence on Athletic Performance. Current Opinion in Pediatrics 25: 653-58. [CrossRef] [PubMed]

Halberstam, Jack. 2018. Trans*: A Quick and Quirky Account of Gender Variability. Berkeley: University of California Press.

Hancock, Ange-Marie. 2004. The Politics Of Disgust: The Public Identity of the Welfare Queen. New York: NYU Press.

Herman, Didi. 1997. The Antigay Agenda: Orthodox Vision and the Christian Right. Chicago: University of Chicago Press.

Hill, Darryl B., and Brian L. B. Willoughby. 2005. The Development and Validation of the Genderism and Transphobia Scale. Sex Roles 53: 531-44. [CrossRef]

January, Brianna. 2021. Fox News Has Aired More Segments on Trans Athletes so Far in 2021 than It Did in the Last Two Years Combined. Media Matters for America. Available online: https:/ / www.mediamatters.org/fox-news/fox-news-has-aired-moresegments-trans-athletes-so-far-2021-it-did-last-two-years-combined (accessed on 6 May 2021).

Johnson, Ashland, Liam Miranda, and Mark Lee. 2018. Play to Win: Improving the Lives of LGBTQ Youth in Sports. Washington: Human Rights Campaign Foundation. Available online: https:/ / assets2.hrc.org/files/assets / resources /PlayToWin-FINAL.pdf?_ga=2.28 099006.300407420.1582836585-1986322191.1582510625 (accessed on 24 May 2021).

Jones, Bethany Alice, Jon Arcelus, Walter Pierre Bouman, and Emma Haycraft. 2017. Sport and Transgender People: A Systematic Review of the Literature Relating to Sport Participation and Competitive Sport Policies. Sports Medicine 47: 701-16. [CrossRef]

Jones, Philip Edward, Paul R. Brewer, Dannagal G. Young, Jennifer L. Lambe, and Lindsay H. Hoffman. 2018. Explaining Public Opinion toward Transgender People, Rights, and Candidates. Public Opinion Quarterly 82: 252-78. [CrossRef]

Jordan-Young, Rebecca, and Katrina Karkazis. 2019. Testosterone: An Unauthorized Biography. Cambridge: Harvard University Press.

Jordan-Young, Rebecca. 2010. Brain Storm: The Flaws in the Science of Sex Differences. Cambridge: Harvard University Press.

Kalla, Joshua L., and David E. Broockman. 2020. Reducing Exclusionary Attitudes through Interpersonal Conversation: Evidence from Three Field Experiments. American Political Science Review 114: 410-25. [CrossRef]

Karkazis, Katrina, and Rebecca Jordan-Young. 2015. Debating a Testosterone 'Sex Gap'. Science 348: 858-60. [CrossRef]

Karkazis, Katrina, and Rebecca Jordan-Young. 2018. The Powers of Testosterone: Obscuring Race and Regional Bias in the Regulation of Women Athletes. Feminist Formations 30: 1-39. [CrossRef]

Karkazis, Katrina, Rebecca Jordan-Young, Georgiann Davis, and Silvia Camporesi. 2012. Out of Bounds? A Critique of the New Policies on Hyperandrogenism in Elite Female Athletes. The American Journal of Bioethics 12: 3-16. [CrossRef]

Karkazis, Katrina. 2008. Fixing Sex: Intersex, Medical Authority, and Lived Experience. Durham: Duke University Press.

Karkazis, Katrina. 2019. The Misuses of 'Biological Sex'. The Lancet 394: 1898-99. [CrossRef]

Kidd, Kacie M., Gina M. Sequeira, Taylor Paglisotti, Sabra L. Katz-Wise, Traci M. Kazmerski, Amy Hillier, Elizabeth Miller, and Nadia Dowshen. 2021. 'This Could Mean Death for My Child': Parent Perspectives on Laws Banning Gender-Affirming Care for Transgender Adolescents. Journal of Adolescent Health 68: 1082-88. [CrossRef]

Klecker, Matt. 2019. Boys Can Join Girls on Minnesota High School Competitive Dance Teams. Star Tribune. Available online: https: //www.startribune.com/boys-can-join-girls-on-high-school-competitive-dance-teams/508927652/ (accessed on 17 February 2021).

Kliegman, Julie. 2021. Current and Former Transgender College Athletes Pressure NCAA on Stance. Sports Illustrated. Available online: https:/ / www.si.com/college/2021/05/26/current-former-transgender-college-athletes-pressure-ncaa-stance (accessed on 26 May 2021).

Koss, Maddie. 2017. No, They're Not Boys. But Madison Soccer Team Endures Criticism Because Players Have Short Hair. Milwaukee Journal Sentinel. Available online: http://www.jsonline.com/story/news/2017/08/05/madison-girls-soccer-team-bristlescritics-who-say-players-boys /459741001/ (accessed on 8 August 2017).

Kruse, Kevin. 2005. White Flight: Atlanta and the Making of Modern Conservatism. Princeton: Princeton University Press.

Kurth, Aren E., Jae A. Puckett, and Kaston D. Anderson-Carpenter. 2021. Legislation Restricting Access to Public Restrooms and Changing Facilities for Transgender Individuals in Texas (US): A Qualitative Analysis of Testimony. International Journal of Transgender Health. [CrossRef]

Lamba Legal Defense and Education Fund. 2020. Brief of Amici Curiae 176 Athletes in Women's Sports, The Women's Sports Foundation, and Athlete Ally in Support of Plaintiffs-Appellees and Affirmance, Hecox v. Little. Available online: https: //www.lambdalegal.org/in-court/legal-docs/hecox_id_20201221_amicus-176-athletes-et-al (accessed on 8 May 2021).

Lax, Jeffrey R., and Justin H. Phillips. 2009. Gay Rights in the States: Public Opinion and Policy Responsiveness. American Political Science Review 103: 367-86. [CrossRef]

Leong, Nancy. 2018. Against Women's Sports. Washington University Law Review 95: 1249-90. [CrossRef]

Levin, Sam. 2021. Mapping the Anti-Trans Laws Sweeping America: 'A War on 100 Fronts.'. The Guardian. Available online: https: / / www.theguardian.com/society/2021/jun/14/anti-trans-laws-us-map (accessed on 9 July 2021).

Liptak, Adam. 2020. Civil Rights Law Protects Gay and Transgender Workers, Supreme Court Rules. New York Times. Available online: https:/ / www.nytimes.com/2020/06/15/us/gay-transgender-workers-supreme-court.html (accessed on 8 May 2021). 
Loffman, Matt. 2021. New Poll Shows Americans Overwhelmingly Oppose Anti-Transgender Laws. PBS News Hour. Available online: https:/ / www.pbs.org/newshour/politics/new-poll-shows-americans-overwhelmingly-oppose-anti-transgender-laws (accessed on 8 May 2021).

Love, Adam, and Kimberly Kelly. 2011. Equity or Essentialism? U.S. Courts and the Legitimation of Girls' Teams in High School Sport. Gender \& Society 25: 227-49.

Luker, Kristin. 1984. Abortion and the Politics of Motherhood. Berkeley: University of California Press.

Luker, Kristin. 1996. Dubious Conception: The Politics of Teenage Pregnancy. Cambridge: Harvard University Press.

Macur, Juliet, and Michael Levenson. 2021. Inspector General Says F.B.I. Botched Nassar Abuse Investigation. New York Times. Available online: https:/ / www.nytimes.com/2021/07/14/sports/olympics/fbi-nassar-report.html (accessed on 14 July 2021).

McDonagh, Eileen, and Laura Pappano. 2007. Playing With the Boys: Why Separate Is Not Equal in Sports. New York: Oxford University Press.

McKinney, Kelsey. 2019. More High School Girls Are Playing Tackle Football Than Ever. Deadspin. Available online: https: / / deadspin.com/more-high-school-girls-are-playing-tackle-football-than-1837378141 (accessed on 8 May 2021).

Meadow, Tey. 2018. Trans Kids: Being Gendered in the Twenty-First Century. Berkeley: University of California Press.

Mele, Christopher. 2017. 'They Thought I Was a Boy': Short-Haired Girl Barred From Soccer Tournament. New York Times. Available online: https: / / www.nytimes.com/2017/06/06/sports/girl-soccer-player.html?_r=0 (accessed on 7 August 2017).

Messner, Michael, and Michela Musto. 2016. Child's Play: Sport in Kids' Worlds. New Brunswick: Rutgers University Press.

Miller, Patrick R., Andrew R. Flores, Donald P. Haider-Markel, Daniel C. Lewis, Barry L. Tadlock, and Jami K. Taylor. 2017. Transgender Politics as Body Politics: Effects of Disgust Sensitivity and Authoritarianism on Transgender Rights Attitudes. Politics, Groups, and Identities 5: 4-24. [CrossRef]

Milner, Adrienne N., and Jomills Henry Braddock. 2016. Sex Segregation in Sports: Why Separate Is Not Equal. New York: Praeger.

Minter, Shannon Price. 2017. 'Déjà vu All Over Again': The Recourse to Biology by Opponents of Transgender Equality. North Carolina Law Review 95: 1161.

Miras, Nicholas S., and Stella M. Rouse. 2021. Partisan Misalignment and the Counter-Partisan Response: How National Politics Conditions Majority-Party Policy Making in the American States. British Journal of Political Science. [CrossRef]

Mosier, Chris. 2021. Transathlete. Available online: https://www.transathlete.com/ (accessed on 19 January 2021).

Movement Advancement Project (MAP). 2021a. Equality Maps: Safe School Laws. Available online: https://www.lgbtmap.org/ equality-maps/safe_school_laws/discrimination (accessed on 15 January 2021).

Movement Advancement Project (MAP). 2021b. LGBTQ Policy Spotlight: Eforts to Ban Health Care for Transgender Youth. Boulder: MAP. Available online: https:/ / www.lgbtmap.org/file/policy-spotlight-trans-health-care-bans.pdf (accessed on 30 July 2021).

Murakawa, Naomi. 2014. The First Civil Right: Racial Liberalism and the Rise of Prison America. New York: Oxford University Press.

Murib, Zein. 2020. Administering Biology: How ‘Bathroom Bills' Criminalize and Stigmatize Trans and Gender Nonconforming People in Public Space. Administrative Theory \& Praxis 42: 153-71.

Musto, Michela, and P. J. McGann. 2016. Strike a Pose! The Femininity Effect in Collegiate Women's Sport. Sociology of Sport Journal 33: 101-12. [CrossRef]

Musto, Michela, Cheryl Cooky, and Michael A. Messner. 2017. 'From Fizzle to Sizzle!' Televised Sports News and the Production of Gender-Bland Sexism. Gender E Society 31: 573-96.

Nance, Penny Young. 2021. Letter of Endorsement: Protection of Women and Girls in Sports Act of 2021. Concerned Women for America. Available online: https: / concernedwomen.org/wp-content/uploads/2021/02/Protection-of-Women-and-Girls-in-Sports-Act2021-CWA-letter.pdf (accessed on 21 May 2021).

Nanney, Megan, and David L. Brunsma. 2017. Moving Beyond Cis-Terhood: Determining Gender through Transgender Admittance Policies at U.S. Women's Colleges. Gender E Society 31: 145-70.

National Collegiate Athletic Association (NCAA). 2014. NCAA Sports Sponsorship and Participation Rates Report, 1981-82-2013-14. Indianapolis: National Collegiate Athletic Association.

National Collegiate Athletic Association (NCAA). 2016. NCAA to Relocate Championships from North Carolina for 2016-17. NCAA.org. Available online: https://www.ncaa.org/about/resources/media-center/news/ncaa-relocate-championships-north-carolina2016-17 (accessed on 8 May 2021).

National Collegiate Athletic Association (NCAA). 2017. 45 Years of Title IX: The Status of Women in Intercollegiate Athletics. Indianapolis: National Collegiate Athletic Association.

National Collegiate Athletic Association (NCAA). 2021. NCAA Demographics Database. NCAA.org. Available online: https: / / www.ncaa.org/about/resources/research/ncaa-demographics-database (accessed on 11 May 2021).

National Federation of High Schools (NFHS). 2019. 2018-19 High School Athletics Participation Survey. High School Participation Survey Archive. Available online: https://www.nfhs.org/media/1020412/2018-19_participation_survey.pdf (accessed on 3 March 2021).

National Women's Law Center (NWLC). 2020. Amicus Brief, National Women's Law Center et Al. in Hecox v. Little. National Women's Law Center Blog. Available online: https:/ / nwlc.org/resources/hecox-v-little/ (accessed on 15 January 2021).

National Women's Law Center (NWLC), and Poverty \& Race Research Action Council (PRRAC). 2015. Finishing Last: Girls of Color and School Sports Opportunities. Washington: National Women's Law Center. 
Novkov, Julie. 2001. Constituting Workers, Protecting Women: Gender, Law and Labor in the Progressive Era and New Deal Years. Ann Arbor: University of Michigan Press.

Novkov, Julie. 2008. Racial Union: Law, Intimacy, and the White State in Alabama, 1865-1954. Ann Arbor: University of Michigan Press.

Novkov, Julie. 2019. Law, Policy, and Sexual Abuse in the \#MeToo Movement: USA Gymnastics and the Agency of Minor Athletes. Journal of Women, Politics \& Policy 40: 42-74.

Office for Civil Rights in the U.S. Department of Education. 2020. Revised Letter of Impending Enforcement Action, CIAC and CT School Districts; Washington, DC: U.S. Department of Education. Available online: https://www2.ed.gov/about/offices/list/ocr/docs/ investigations/more/01194025-a2.pdf (accessed on 8 May 2021).

Orr, Gabby. 2020. The Wedge Issue That's Dividing Trumpworld. Politico. Available online: https://www.politico.com/news/ magazine/2020/08/07/wedge-issue-dividing-trumpworld-392323 (accessed on 8 May 2021).

Paluck, Elizabeth Levy, and Chelsey S. Clark. 2020. Can Playing Together Help Us Live Together? Science 369: 769-70. [CrossRef]

Pearce, Ruth, Sonja Erikainen, and Ben Vincent. 2020. TERF Wars: An Introduction. Sociological Review 68: 677-98. [CrossRef]

Peters, Jeremy. 2019. A Conservative Push to Make Trans Kids and School Sports the Next Battleground in the Culture War. New York Times. Available online: https://www.nytimes.com/2019/11/03/us/politics/kentucky-transgender-school-sports.html (accessed on 17 February 2021).

Pickett, Moneque Walker, Marvin P. Dawkins, and Jomills Henry Braddock. 2012. Race and Gender Equity in Sports: Have White and African American Females Benefited Equally From Title IX?". American Behavioral Scientist 56: 1581-603. [CrossRef]

Pieper, Lindsay Parks. 2012. Gender Regulation: Renée Richards Revisited. International Journal of the History of Sport 29: 675-90. [CrossRef]

Pieper, Lindsay Parks. 2016. Sex Testing: Gender Policing in Women's Sports. Urbana-Champagne: University of Illinois Press.

Ranković, Goran, Vlada Mutavdžić, Dragan Toskić, Adem Preljević, Miodrag Kocić, Gorana Nedin-Ranković, and Nikola Damjanović. 2010. Aerobic Capacity as an Indicator in Different Kinds of Sports. Bosnian Journal of Basic Medical Sciences 10: 44-48. [CrossRef]

Republican National Committee (RNC). 2016. Republican Party Platform 2016. Santa Barbara: The American Presidency Project, University of California Santa Barbara. Available online: https://www.presidency.ucsb.edu/documents/2016-republican-partyplatform (accessed on 5 May 2021).

Richardson, Sarah. 2015. Sex Itself: The Search for Male and Female in the Human Genome. Chicago: University of Chicago Press.

Roberts, Dorothy E. 1997. Killing the Black Body: Race, Reproduction, and the Meaning of Liberty. New York: Pantheon Books.

Roberts, Timothy A., Joshua Smalley, and Dale Ahrendt. 2021. Effect of Gender Affirming Hormones on Athletic Performance in Transwomen and Transmen: Implications for Sporting Organisations and Legislators. British Journal of Sports Medicine 55: 577-83. [CrossRef]

Rose, Deondra. 2018. Citizens by Degree: Higher Education Policy and the Changing Gender Dynamics of American Citizenship. New York: Oxford University Press.

Sabo, Don, Philip Veliz, and Ellen J. Staurowsky. 2016. Beyond X's and O's: Gender Bias and Coaches of Women's College Sports. East Meadow: Women's Sports Foundation.

Schilt, Kristen, and Laurel Westbrook. 2009. Doing Gender, Doing Heteronormativity: 'Gender Normals,' Transgender People, and the Social Maintenance of Heterosexuality. Gender \& Society 23: 440-64.

Schilt, Kristen, and Laurel Westbrook. 2015. Bathroom Battlegrounds and Penis Panics. Contexts 14: 26-31. [CrossRef]

Schreiber, Ronnee. 2008. Righting Feminism: Conservative Women and American Politics. New York: Oxford University Press.

Self, Robert. 2012. All in the Family: The Realignment of American Democracy Since the 1960s. New York: Farrar, Straus and Giroux.

Sharrow, Elizabeth, Jesse Rhodes, Tatishe Nteta, and Jill Greenlee. 2018. The First Daughter Effect: The Impact of Fathering First Daughters on Men's Preferences on Gender Equality Issues. Public Opinion Quarterly 82: 493-523. [CrossRef]

Sharrow, Elizabeth. 2017. 'Female Athlete' Politic: Title IX and the Naturalization of Sex Difference in Public Policy. Politics, Groups, and Identities 5: 46-66. [CrossRef]

Sharrow, Elizabeth. 2020a. A 'Bridge to Our Daughters': Title IX Fathers and Policy Development. In Stating the Family: New Directions in the Study of American Politics. Edited by Julie Novkov and Carol Nackenoff. Lawrence: University Press of Kansas, pp. 127-63.

Sharrow, Elizabeth. 2020b. How High School Sports Became the Latest Battleground over Transgender Rights. The Conversation. Available online: https: / / theconversation.com/how-high-school-sports-became-the-latest-battleground-over-transgenderrights-151361 (accessed on 22 December 2020).

Sharrow, Elizabeth. 2021. Sex Segregation as Policy Problem: A Gendered Policy Paradox. Politics, Groups, and Identities 9: 258-79. [CrossRef]

Shuster, Stef. 2021. Trans Medicine: The Emergence and Practice of Treating Gender. New York: New York University Press.

Snorton, C. Riley. 2017. Black on Both Sides: A Racial History of Trans Identity. Minneapolis: University of Minnesota Press.

Soss, Joe, Richard C. Fording, and Sanford F. Schram. 2011. Disciplining the Poor: Neoliberal Paternalism and the Persistent Power of Race. Chicago: University of Chicago Press.

Southern Poverty Law Center (SPLC). 2021. Alliance Defending Freedom. Extremist Files. Available online: https://www.splcenter. org/fighting-hate/extremist-files/group/alliance-defending-freedom (accessed on 8 May 2021).

Staurowsky, Ellen J., Nicholas Watanabe, Joseph Cooper, Cheryl Cooky, Nancy Lough, Amanda Paule-Koba, Jennifer Pharr, Sarah Williams, Sarah Cummings, Karen Issokson-Silver, and et al. 2020. Chasing Equity: The Triumphs, Challenges, and Opportunities in Sports for Girls and Women. New York: Women's Sports Foundation. 
Staurowsky, Ellen, Mary Jane De Souza, Kathleen E. Miller, Don Sabo, Sohaila Shakib, Nancy Theberge, P. Veliz, A. Weaver, and Nancy I. Williams. 2015. Her Life Depends On It III: Sport, Physical Activity, and the Health and Well-Being of American Girls and Women. East Meadow: Women's Sports Foundation.

Stelzer, Beth. 2019. Save Women's Sports Website. Available online: https:/ / savewomenssports.com/ (accessed on 21 May 2021).

Stone, Amy L. 2018. Gender Panics about Transgender Children in Religious Right Discourse. Journal of LGBT Youth 15: 1-15. [CrossRef]

Stratford, Michael. 2020. Court Rules 'resoundingly Yes' for Transgender Rights in Gavin Grimm Bathroom Access Battle. Politico. Available online: https:/ / www.politico.com/news/2020/08/26/court-yes-transgender-rights-gavin-grimm-bathroom-402532 (accessed on 15 January 2021).

Strum, Philippa. 2002. Women in the Barracks: The VMI Case and Equal Rights. Lawrence: University Press of Kansas.

Taylor, Jami K. 2007. Transgender Identities and Public Policy in the United States. Administration E Society 39: 833-56.

Taylor, Jami K., Daniel C. Lewis, and Donald P. Haider-Markel. 2018. The Remarkable Rise of Transgender Rights. Ann Arbor: University of Michigan Press.

Taylor, Jami K., Daniel C. Lewis, and Donald P. Haider-Markel. 2021. LGBTQ Policy and Fragmented Federalism in the U.S. State and Local Government Review 52: 255-65. [CrossRef]

Travers, Ann. 2016. Transgender and Gender-Nonconforming Kids and the Binary Requirements of Sport Participation in North America. In Child's Play: Sport in Kids' Worlds. Edited by Michael A. Messner and Michela Musto. New Brunswick: Rutgers University Press, pp. 179-201.

Travers. 2018. The Trans Generation: How Trans Kids (and Their Parents) Are Creating a Gender Revolution. New York: NYU Press.

Trevor Project. 2020. The Trevor Project Research Brief: The Well-Being of LGBTQ Youth Athletes. Available online: https://www. thetrevorproject.org/2020/08/31/research-brief-the-well-being-of-lgbtq-youth-athletes/ (accessed on 8 May 2021).

Tucker, Ross, and Malcolm Collins. 2012. What Makes Champions? A Review of the Relative Contribution of Genes and Training to Sporting Success. British Journal of Sports Medicine 46: 555-61. [CrossRef] [PubMed]

Turban, Jack L., Katherine Kraschel, and I. Glenn Cohen. 2021. Legislation to Criminalize Gender-Affirming Medical Care for Transgender Youth. JAMA: The Journal of the American Medical Association 325: 2251-52. [CrossRef]

Turk, Katherine. 2016. Equality on Trial: Gender and Rights in the Modern American Workplace. Philadelphia: University of Pennsylvania Press.

United States Department of Education (DOE). 1979. Title IX Regulations. [44 FR 17168, Mar. 21, 1979]. Available online: http: / / www2.ed.gov/policy/rights/reg/ocr/edlite-34cfr106.html\#S57 (accessed on 24 May 2021).

United States Department of Education (DOE). 2016. Dear Colleague Letter on Transgender Students. Available online: https: / / www2.ed.gov/about/offices/list/ocr/letters/colleague-201605-title-ix-transgender.pdf (accessed on 26 March 2021).

United States Department of Education (DOE). 2017. Dear Colleague Letter. Available online: https://www2.ed.gov/about/offices/ list/ocr/letters/ colleague-201702-title-ix.pdf (accessed on 26 March 2021).

United States Department of Education (DOE). 2021. U.S. Department of Education Confirms Title IX Protects Students from Discrimination Based on Sexual Orientation and Gender Identity. Available online: https:/ /www.ed.gov/news /press-releases/usdepartment-education-confirms-title-ix-protects-students-discrimination-based-sexual-orientation-and-gender-identity (accessed on 20 June 2021).

United States Department of Health and Human Services (DHHS). 2021. Health and Human Services Grants Regulation. 45 CFR Part 75. Available online: https://www.hhs.gov/sites/default/files/hhs-grants-regulation.pdf (accessed on 8 May 2021).

United States Department of Justice (DOJ). 2020a. United States Statement of Interest in Hecox v. Little. Available online: https: / / www.aclu.org/legal-document/united-states-statement-interest (accessed on 8 May 2021).

United States Department of Justice (DOJ). 2020b. United States Statement of Interest in Soule et Al. v. CIAC et Al. Available online: https:/ / www.aclu.org/legal-document/ soule-et-al-v-ct-association-schools-et-al-trump-admin-statement-interest (accessed on 8 May 2021).

United States Department of Justice (DOJ). 2021. Application of Bostock v. Clayton County to Title IX of the Education Amendments of 1972; Washington, DC: U.S. Department of Justice Civil Rights Division. Available online: https://www.justice.gov/crt/page/file/13 83026/download (accessed on 8 May 2021).

U.S. Congress. 2021. The Equality Act: LGBTQ Rights Are Human Rights. Available online: https://www.judiciary.senate.gov/ meetings/the-equality-act-lgbtq-rights-are-human-rights (accessed on 17 March 2021).

Vejar, Alex. 2021. Federal Judge Rules against Girls Trying to Create Sanctioned, Separate High School Football in Utah. Salt Lake Tribune. Available online: https://www.sltrib.com/sports/high-school-sports/2021/03/02/judge-rules-against-girls / (accessed on 8 May 2021).

Vitulli, Elias. 2010. A Defining Moment in Civil Rights History? The Employment Non-Discrimination Act, Trans-Inclusion, and Homonormativity. Sexuality Research and Social Policy 7: 155-67. [CrossRef]

Wang, Esther. 2019. The Unholy Alliance of Trans-Exclusionary Radical Feminists and the Right Wing. Jezebel. Available online: https:/ /jezebel.com/the-unholy-alliance-of-trans-exclusionary-radical-femin-1834120309 (accessed on 8 May 2021).

Ware, Susan. 2011. Game, Set, Match: Billie Jean King and the Revolution in Women's Sports. Chapel Hill: University of North Carolina Press. 
Weigel, David. 2021. Why Republicans Keep Running Against Trans Rights. Washington Post. Available online: https://www. washingtonpost.com/politics/2021/03/02/trailer-why-republicans-keep-running-against-trans-rights/ (accessed on 21 May 2021).

West, Candace, and Don H. Zimmerman. 1987. Doing Gender. Gender E Society 1: 125-51.

West, Jenna. 2020. Billie Jean King, Megan Rapinoe and Candace Parker Support Brief Against Idaho Anti-Transgender Law. Sports Illustrated. Available online: https:/ / www.si.com/more-sports/2020/12/21/idaho-anti-transgender-law-briefs (accessed on 8 January 2021).

Westbrook, Laurel, and Kristen Schilt. 2014. Doing Gender, Determining Gender: Transgender People, Gender Panics, and the Maintenance of the Sex/Gender/Sexuality System. Gender E Society 28: 32-57.

Westbrook, Laurel, and Kristen Schilt. 2015. Penis Panics, Biological Maleness, Social Masculinity, and the Matrix of Perceived Sexual Threat. In Exploring Masculinities: Identity, Inequality, Continuity and Change. Edited by C. J. Pascoe and Tristan Bridges. New York: Oxford University Press, pp. 382-93.

Whisenant, Warren A. 2003. How Women Have Fared as Interscholastic Athletic Administrators since the Passage of Title IX. Sex Roles 49: 179-84. [CrossRef]

White House. 2021. Executive Order on Preventing and Combating Discrimination on the Basis of Gender Identity or Sexual Orientation. Available online: https://www.whitehouse.gov/briefing-room/presidential-actions/2021/01/20/executive-orderpreventing-and-combating-discrimination-on-basis-of-gender-identity-or-sexual-orientation/ (accessed on 22 January 2021).

Women's Sports Foundation (WSF). 2021. WSF Statement on President Biden's 'Executive Order on Preventing and Combating Discrimination on the Basis of Gender Identity or Sexual Orientation'. Available online: https:/ /www.womenssportsfoundation. org/media_statement/wsf-statement-on-president-bidens-executive-order-on-preventing-and-combating-discrimination-onthe-basis-of-gender-identity-or-sexual-orientation/ (accessed on 8 May 2021).

Women's Sports Policy Working Group (WSPWG). 2021. A Request to Congress and the Administration to Safeguard Girls' and Women's Sport \& Include Transgender Athletes. Briefing Book. Available online: https://womenssportspolicy.org/wp-content/ uploads/2021/02/Congressional-Briefing-WSPWG-Transgender-Women-Sports-2.27.21.pdf (accessed on 21 May 2021).

Wuest, Joanna. 2019. The Scientific Gaze in American Transgender Politics: Contesting the Meanings of Sex, Gender, and Gender Identity in the Bathroom Rights Cases. Politics \& Gender 15: 336-60.

Wuest, Joanna. 2021. A Conservative Right to Privacy: Legal, Ideological, and Coalitional Transformations in US Social Conservatism. Law \& Social Inquiry. [CrossRef]

YouGov. 2017. Title IX and Girls in Sport. East Meadow: Women's Sports Foundation. 